المجلة اللدولية اللملوم الأسانية والإجتاعياة International Journal of Humanities and Social Sciences website:www.ijohss.com Email:editor@ijohss.com ISSN: $2415-4822$

العدد (14) أغسطس 2020

Volume (14) August 2020

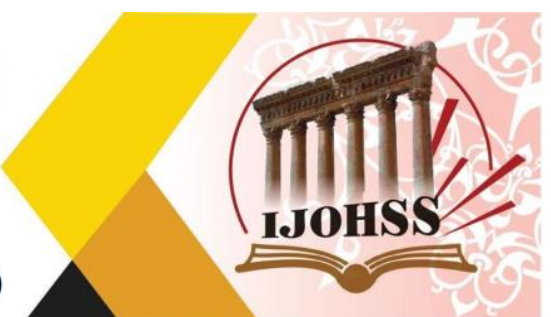

\title{
وثيقة برنامج جودة الحياة 2020 وأثرها في تعزيز الانتماء الوطني
}

\author{
د. د. إلهام عبد الرحيم العلان

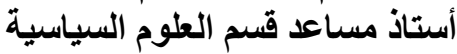

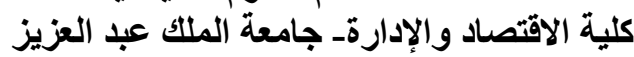 \\ جدة ـ المملكة العربية السعودية المالية
}

|لماخص

هدف هذا البحث إلى التعرف على أثر وثيقة برنامج جودة الحياة 2020 في تعزيز الانتماء الوطني، ولتحقيق ذلك

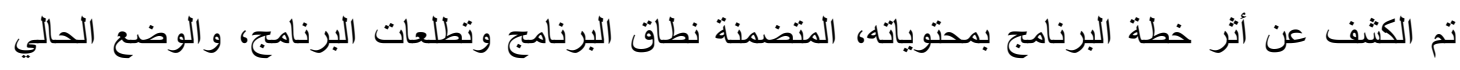
و استر اتيجية البرنامج، و المبادر ات و الجدول الزمني، و المبادرات المحورية و الممكنات، وتمثلت أداة البحث في تحليل تللك المحتويات وربطها بمفهوم الانتماء الوطني. وقد تم اعتماد المنهج الوصفي كمنهج علمي لتناول البحث.

وقد أثشار التحليل إلى أن وثيقة برنامج جودة الحياة 2020، تساهم في إرساء قواعد أساسية لجودة الحياة في

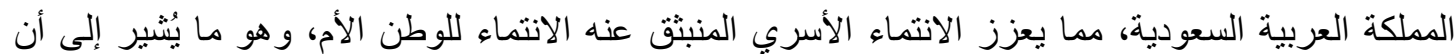

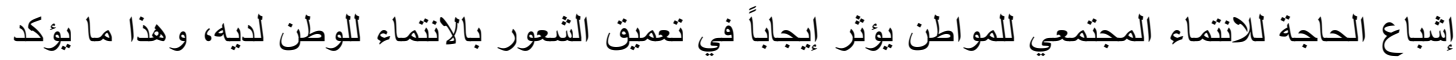
الأثر الإيجابي للاولة في تعزيز الانتماء للوطن من خلال تفعيل وظائفها المختلفة. وفي ختام البحث تم التوصية بجملة من الإجراءات ذات العلاقة بالموضوع، والتي من شأنها تعميق الثعور بالاتنماء للوطن لاى المو اطن من خلال الاستثمار الأمثل لخطة برنامج جودة الحياة 2020.

الكلمات المفتاحية: برنامج جودة الحياة، وثيقة 2020 ، الانتماء الوطني. 


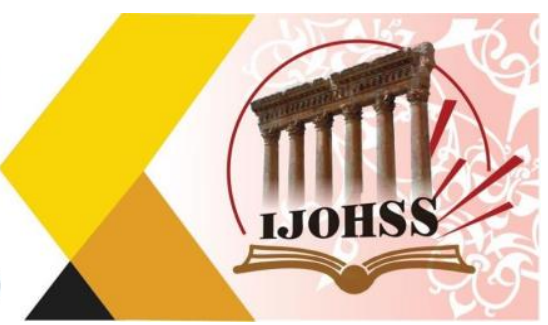

\title{
Quality of Life Program Document 2020 and Its Impact on Enhancing National Affiliation
}

\author{
Dr. Ilham Abdul Rahim Al-Allan \\ Assistant Professor, Department of Political Science \\ Faculty of Economics and Administration - King Abdulaziz University \\ Jeddah-Saudi Arabia
}

\begin{abstract}
This paper is meant to investigate the effect of life quality assurance program 2020 on strengthening the national membership belongingness to achieve this goal, the effect of the program contents that include the program extent, aims, care initiation, strategy was handled. The description approach was used in such investigation the analysis of this document indicates that the program contributes and strengthens the bases of life quality assurance in Saudi Arabia which consolidate the family belongings that leads to homeland belongingness. This means the social belongingness of the country man positively affects his homeland belongingness. This emphasizes the positive effects of the state/ government in supporting the homeland belongingness. At the end of this paper a group of procedures related are recommended, which profound and deepen the homeland belongingness through the ideal exploitation of the quality assurance program 2020.
\end{abstract}

Keywords: Quality of Life Program, 2020 Document, National Affiliation. 
المجلة اللدولية اللملوم الأسانية والإجتاعياة

International Journal of Humanities and Social Sciences

website:www.ijohss.com

Email:editor@ijohss.com

ISSN: $2415-4822$

العدد (14) أغسط 2020

Volume (14) August 2020

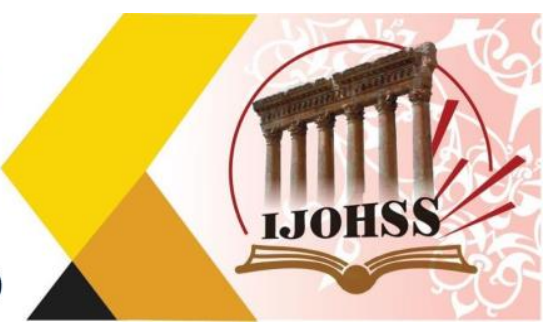

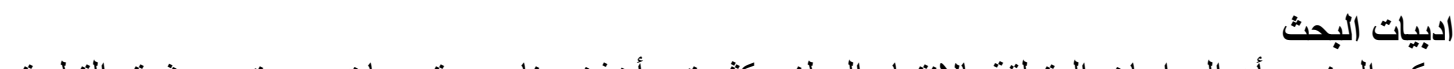

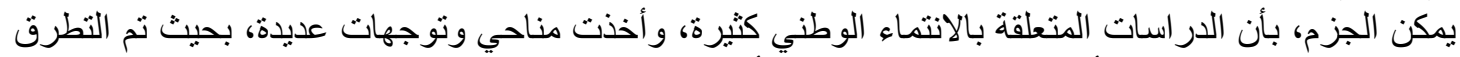

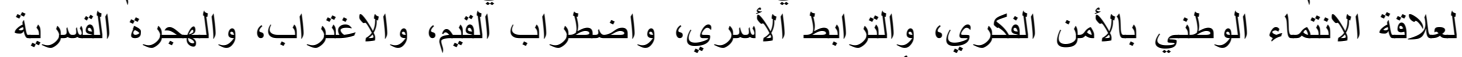

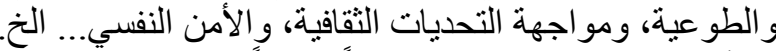

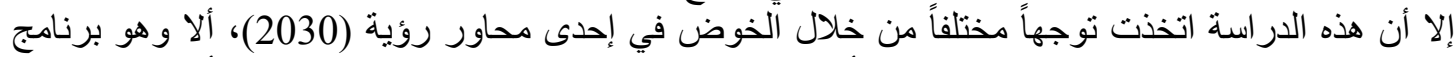

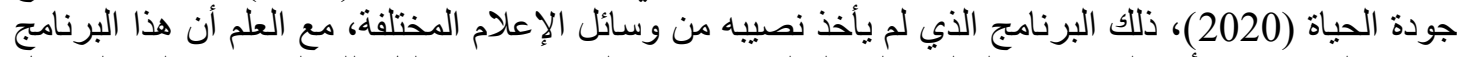

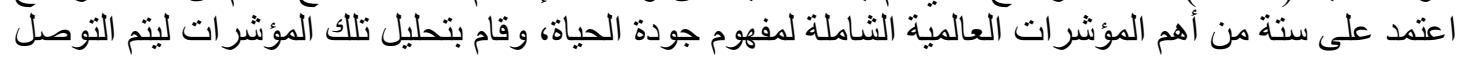

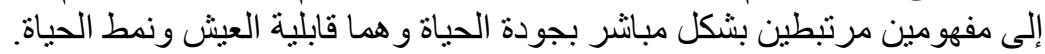

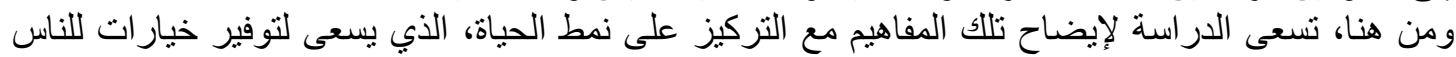

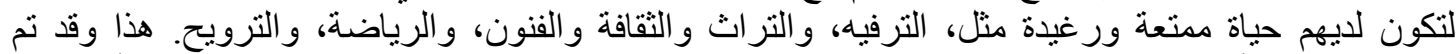

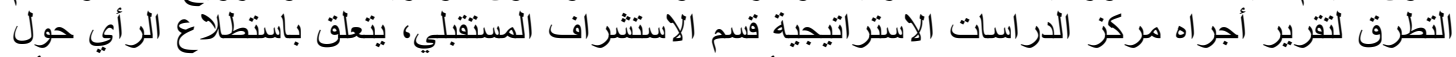

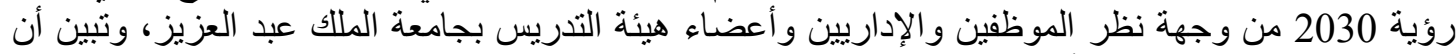

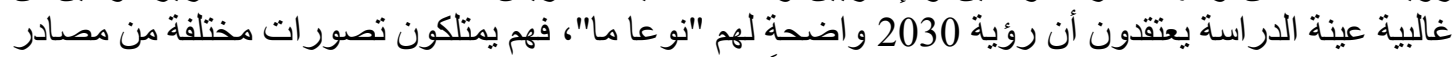

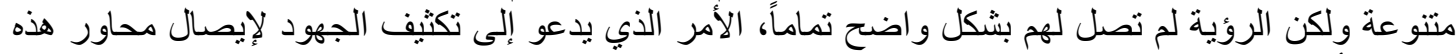

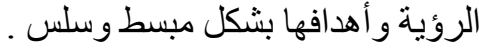

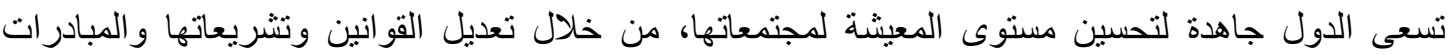

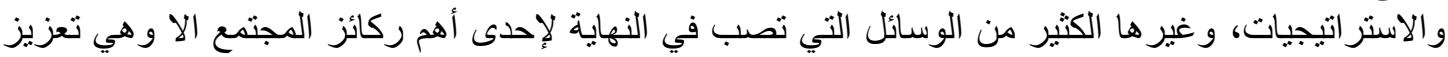

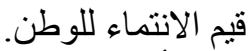

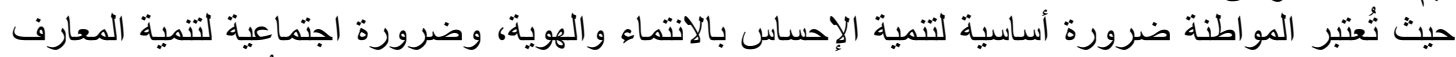

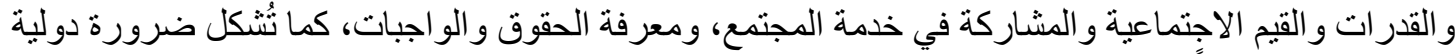

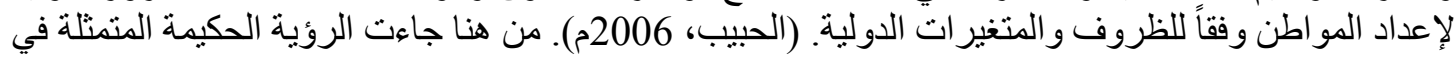

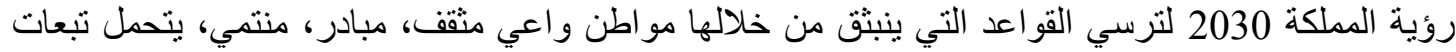

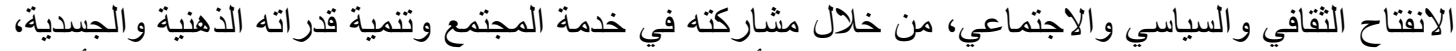

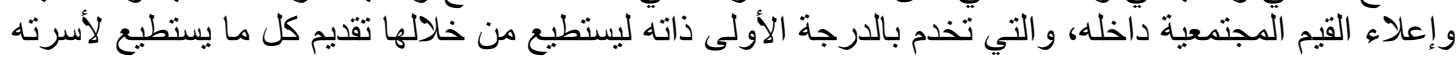

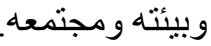
وبناء على ذلك، فقد تم التطرق لجزء هام من أجزاء وبرامج رؤية 2030، وهي وثيقة برنامج جودة الحياة

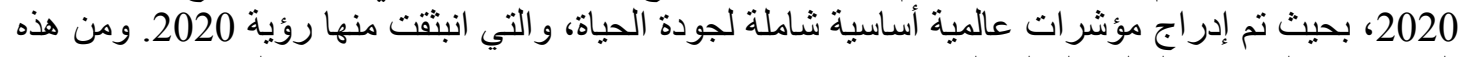

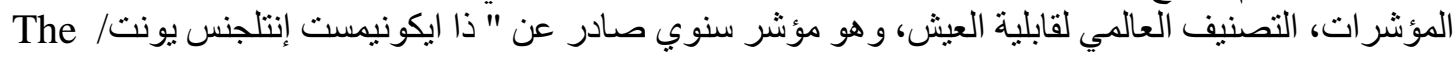
"Economist Intelligence Unit" ويصنف المدن في 140 دولة حسب جودة الحياة الحضرية فيها، بناء على تقييم الاستقرار و الرعاية الصحية

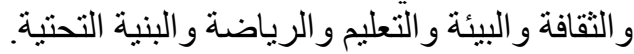

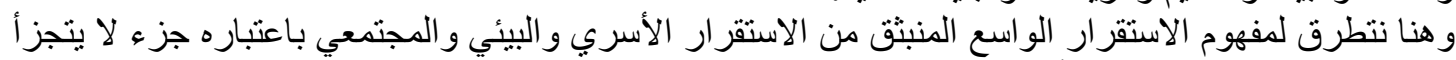

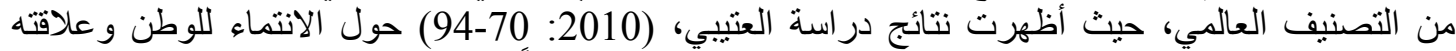

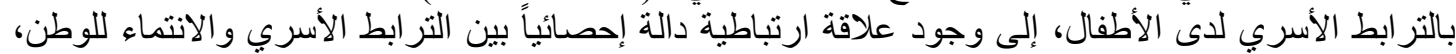

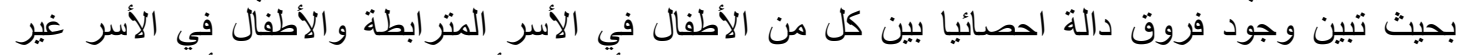

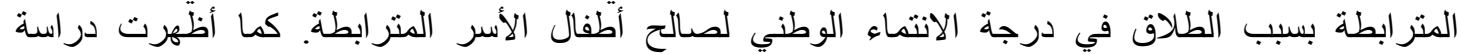

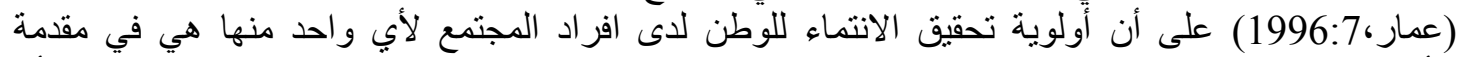

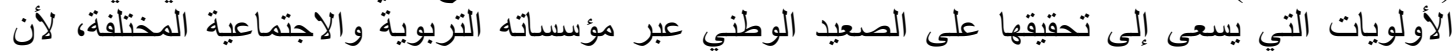

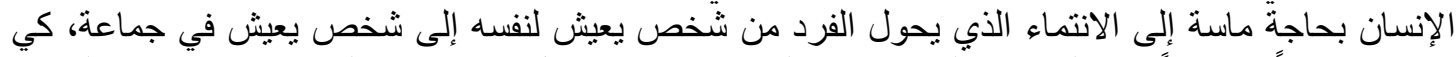

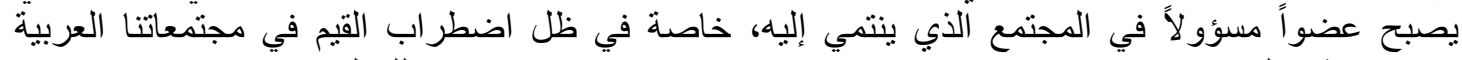

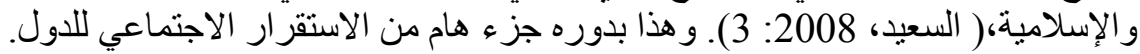


المجلة الحولية اللملوم الآسانية والإمتماعية

International Journal of Humanities and Social Sciences

website:www.ijohss.com

Email:editor@ijohss.com

ISSN: $2415-4822$

العدد (14) أغسطس 2020

Volume (14) August 2020

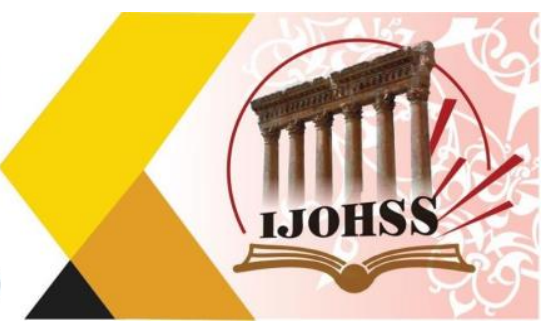

أهداف الدر اسة:

هدف هذا البحث أساسا إلى ما يلي:

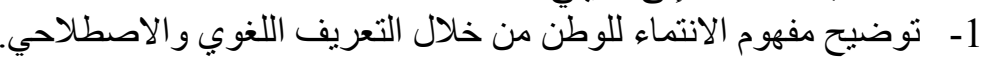

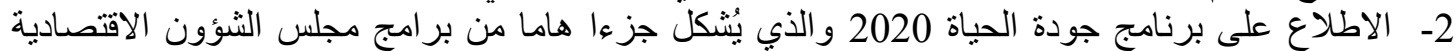
و التنمية الاثني عشر لرؤية المملكة.

3- الكثف عن دور برنامج جودة الحياة 2020 في تعزيز قيم الانتماء للوطن.

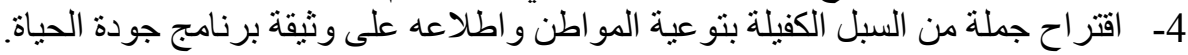

أهمية الاراسة: - ماستة

1- يستقي هذا البحث أهميته من أهمية قيم الانتماء للوطن من ناحية، والاطلاع على جهود القيادة السياسية

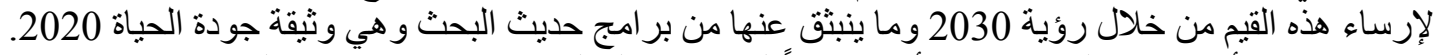

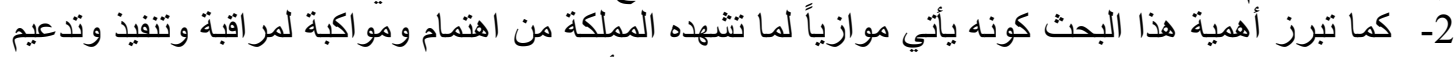

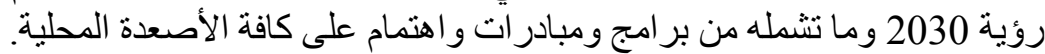

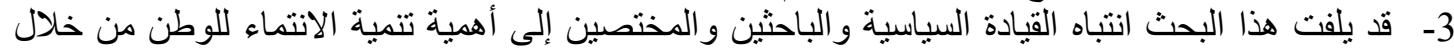
إدر اج وثيقة برنامج جودة الحياة للمقرر ات الدر اسية لزيادة تدعيم قيم الو لاء و الانتماء عند الطلبة.

فروض البحث : 1- توجد فروق ذات دلالة إحصائية بين متوسط درجات أفراد العينة في الانتماء الوطني تبعا لمتغيرات الدر اسة. 2- توجد فروق ذات دلالة إحصائية بين متوسط درجات أفراد العينة في الاطلاع على وثيقة جودة الحياة

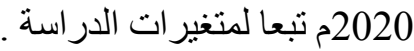
3- توجد فروق ذات دلالة إحصائية بين متوسط درجات أفر اد العينة في الدور الوات اقعي و الفعلي لبرنامج جودة

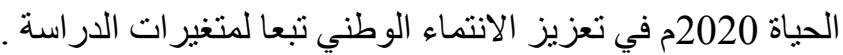
4- توجد علاقة ارتباطية بين محاور استبيان وثيقة برنامج جودة الحياة 2020م و أثر ها على الانتماء الوطني .

منهج الار اسة وأدواتها: اعتمدت الدر اسة على المنهج الوصفي بما بشتهل عليه من جمع الآر اء حول الظاهرة موضوع الدر اسة ووصفها، وذلك من خلال استبانة طبقت على ( ) من موظفي جامعة الملك عبد العزيز خلافل الفصل الفصل الثاني من العام

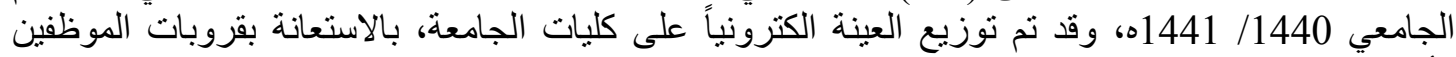
كأسلوب لجمع البيانات.

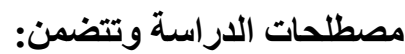
الانتماء الوطني: يدل استقراء المعاجم العربية على أن من معاني كلمة (نَما)، في اللغة: الارتفاع، ومن معاني

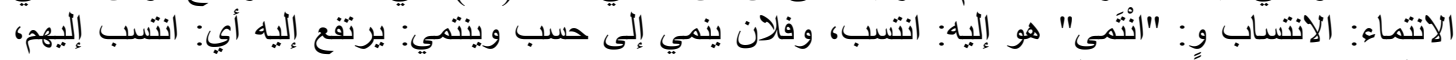

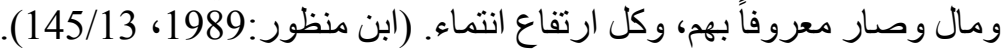
ويُشير الانتماء في المعاجم الإنجليزية إلى كلمة (Belongingness) وترجع في في الأصل إلى كلى كلمة (Belong)

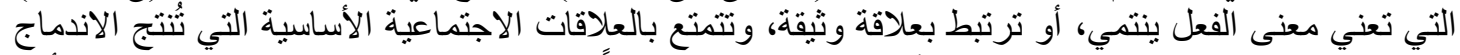

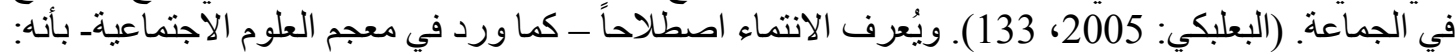
"ارتباط الفرد بجماعةٌ؛ حيث يرغة فب الفرد في الانتماء إلى جماعة قوية يتقمص شخصيتها ويوحد نفسه بهاء بها مثل

الأسرة أو النادي أو الشركة". (بدوي، 1978:16).

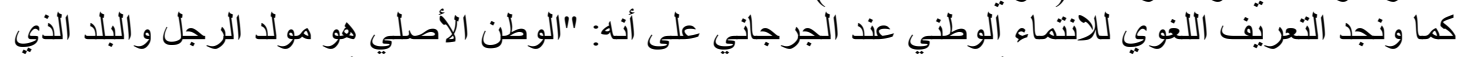

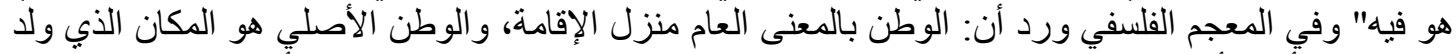

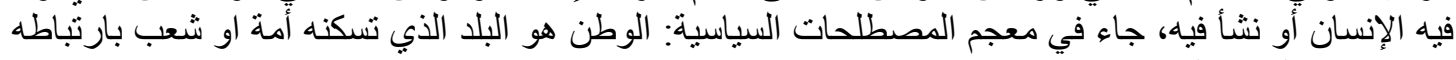
بها وانتهائه إليها. (الثعر اوي، 2008: 


\section{المجلة اللدولية اللملوم الآسانية والإمتصاعية} International Journal of Humanities and Social Sciences website:www.ijohss.com Email:editor@ijohss.com ISSN: $2415-4822$

\section{العدد (14) أغطس 2020 \\ Volume (14) August 2020}

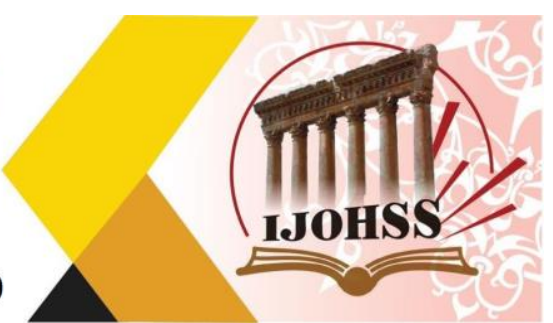

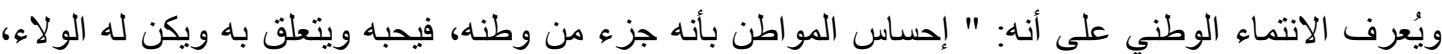

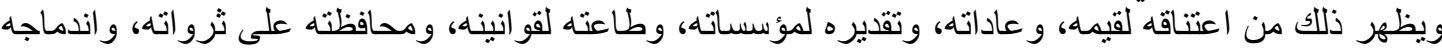

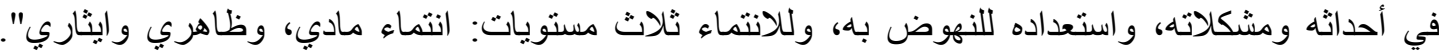

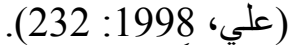

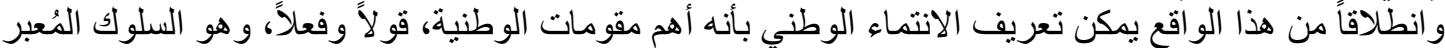

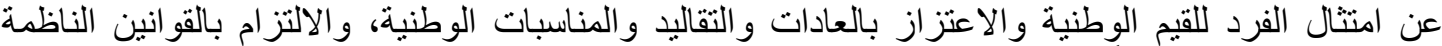

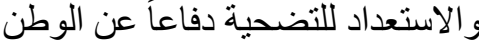
وثيقة برنامج جودة الحياة 2020: (برنامج جودة المباء الحياة 2020:

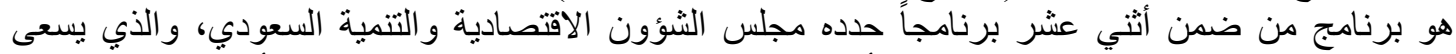

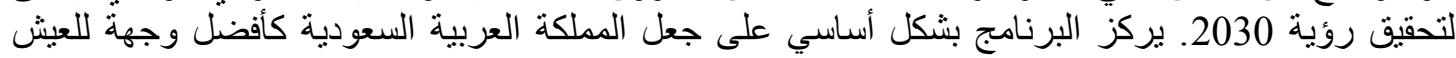

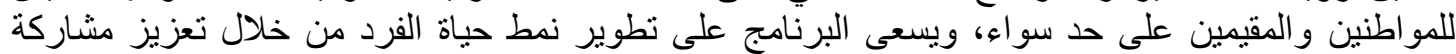

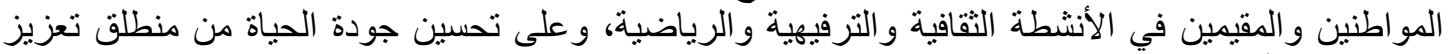

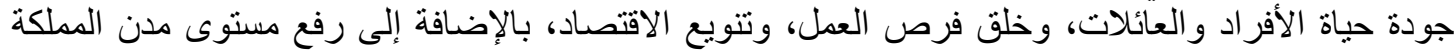

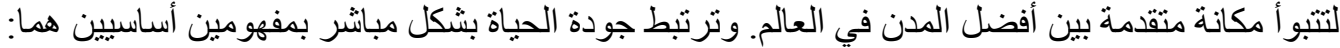

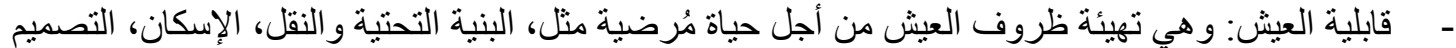

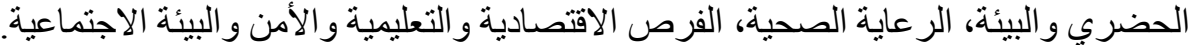

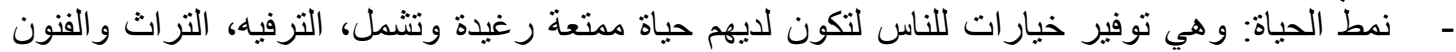
و الثقافة، الرياضة، الترويح، و المشاركة الاجتماعية.

$$
\begin{aligned}
& \text { صدق وثبات أدوات البحث } \\
& \text { صدق الاستبيان : صلات } \\
& \text { يقصد باه قدرة الاستبيان على قياس ما وضع لقياسه . }
\end{aligned}
$$

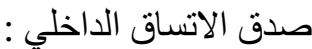

1- حساب معاملات الارتباط بين درجة كل عبارة من العبارات المكونة لكل محور ، و الدرجة الكلية للمحور بالاستبيان 2- حساب معاملات الارتباط بين الدرجة الكلية لكل محور من محاور الاستبيان و الدرجة الكلية للمقياس .

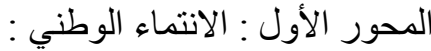
تم حساب الصدق باستخدام الاتساق الداخلي وذللك بحساب معامل الارتباط ( معامل ارتباط بيرسون ) بين

\begin{tabular}{|c|c|c|c|c|c|}
\hline الدلالة & الارتباط & 5 & الدلالة & الارتباط & 5 \\
\hline 0.05 & 0.619 & -6 & 0.01 & 0.805 & -1 \\
\hline 0.01 & 0.782 & -7 & 0.01 & 0.864 & -2 \\
\hline 0.01 & 0.841 & -8 & 0.05 & 0.608 & -3 \\
\hline 0.01 & 0.727 & -9 & 0.05 & 0.632 & -4 \\
\hline 0.01 & 0.819 & -10 & 0.01 & 0.953 & -5 \\
\hline
\end{tabular}

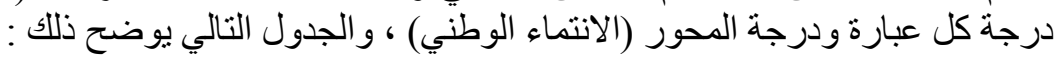
جدول (1) قيم معاملات الارتباط بين درجة كل عبارة ودرجة المحور (الانتماء الوطني)

يتضح من الجدول أن معاملات الارتباط كلها دالة عند مستوى ( 0.01 - 0.05 ) لاقترابها من الواحد

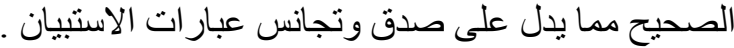
المحور الثاني : الاطلاع على وثيقة جودة الحياة 2020م :

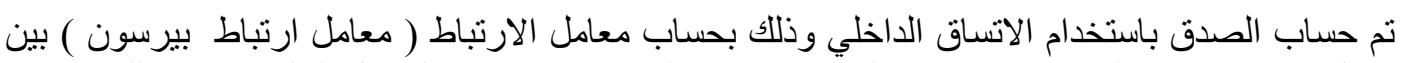
درجة كل عبارة ودرجة المحور (الاطلاع على وثيقة جودة الحياة 2020م) ، والجدول التالي يوضح ذلإنك : 


\section{المجلة اللدولية اللملوم الآسانية والإمتماعية}

International Journal of Humanities and Social Sciences website:www.ijohss.com Email:editor@ijohss.com العدد (14) أغسطس 2020 IJOHSS ISSN: $2415-4822$

Volume (14) August 2020

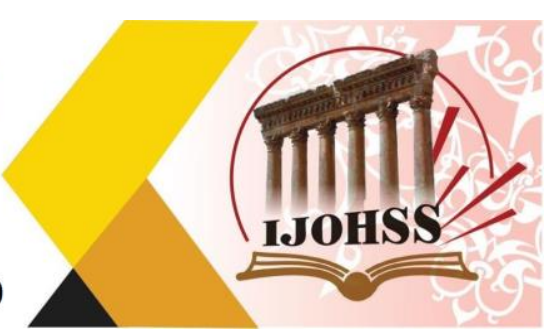

جدول (2) قيم معاملات الارتباط بين درجة كل عبارة

ودرجة المحور (الاطلاع على وثيقة جودة الارثياط درجة الحياة 2020م)

\begin{tabular}{|c|c|c|c|c|c|}
\hline الدلالة & الارتباط & م & الدلالة & الارتباط & ? \\
\hline 0.01 & 0.732 & -6 & 0.01 & 0.934 & -1 \\
\hline 0.01 & 0.824 & -7 & 0.01 & 0.752 & -2 \\
\hline 0.01 & 0.886 & -8 & 0.05 & 0.643 & -3 \\
\hline 0.05 & 0.627 & -9 & 0.01 & 0.876 & -4 \\
\hline 0.01 & 0.763 & -10 & 0.01 & 0.905 & -5 \\
\hline
\end{tabular}

يتضح من الجدول أن معاملات الارتباط كلها دالة عند مستوى ( 0.01 - 0.05 ) لاقتر ابها من الواحد

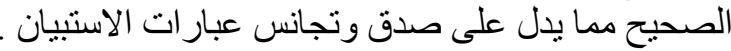

المحور الثالث : الدور الو اقعي والفعلي لبرنامج جودة الحياة 2020م في تعزيز الانتماء الوطني:

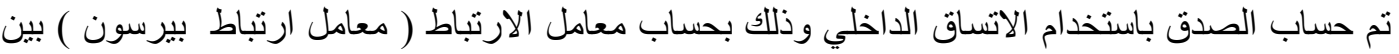

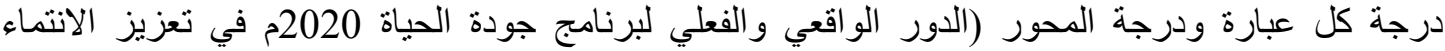

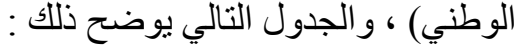

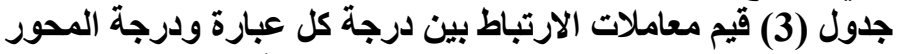

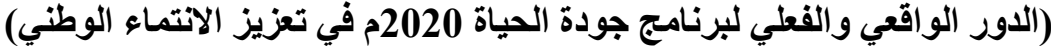

\begin{tabular}{|c|c|c|c|c|c|}
\hline الدلالة & الارتباط & 3 & الدلالة & الارتباط & 5 \\
\hline 0.01 & 0.835 & -9 & 0.01 & 0.709 & -1 \\
\hline 0.05 & 0.644 & -10 & 0.01 & 0.828 & -2 \\
\hline 0.01 & 0.778 & -11 & 0.05 & 0.605 & -3 \\
\hline 0.01 & 0.894 & -12 & 0.05 & 0.639 & -4 \\
\hline 0.01 & 0.717 & -13 & 0.01 & 0.881 & -5 \\
\hline 0.05 & 0.621 & -14 & 0.01 & 0.942 & -6 \\
\hline 0.01 & 0.918 & -15 & 0.05 & 0.612 & -7 \\
\hline & & & 0.01 & 0.767 & -8 \\
\hline
\end{tabular}

يتضح من الجدول أن معاملات الارتباط كلها دالة عند مسنوى ( 0.01 - 0.05 ) لاقتر ابها من الواحد

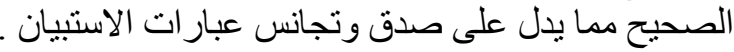

الصدق باستخدام الاتساق الداخلي بين الدرجة الكلية لكل محور و الدرجة الكلية للاستبيان :

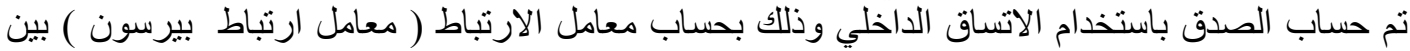

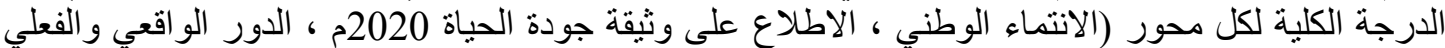

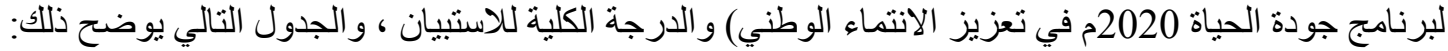




\section{المجلة الحولية اللعلور الأسانية والإمتماعية}

International Journal of Humanities and Social Sciences website:www.ijohss.com Email:editor@ijohss.com ISSN: $2415-4822$

\section{العدد (14) أغطس 2020 \\ Volume (14) August 2020}

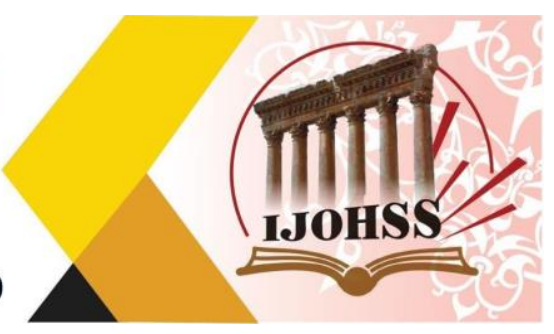

جدول (4) قيم معاملات الارتباط بين الارجة الكلية لكل محور (الانتماء الوطني ، الاطلاع على وثيقة جودة

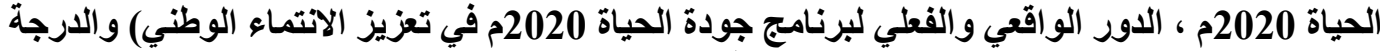
الكلية للاستبيان

\begin{tabular}{|c|c|c|}
\hline الدلالة & الارتباط & \\
\hline 0.01 & 0.737 & المحور الأول : الانتماء الوطني \\
\hline 0.01 & 0.856 & المحور الثاني : الاطلاع على وثيقة جودة الَّياة 2020م \\
\hline 0.01 & 0.795 & جودة الحياة الثيالث : الدور الو اقعي و الفعلي لبرنياء الوطني \\
\hline
\end{tabular}

يتضح من الجدول أن معاملات الارتباط كلها دالة عند مستوى ( 0.01 ) لاقتر ابها من الواحد الصحيح مما يدل على صدق وتجانس محاور الاستبيان . الثبات :

يقصد بالثبات reability دقة الاختبار في القياس و الملاحظة ، و وعدم تناقضه مع نفسه ، و و اتساقه و واطر اده فيما

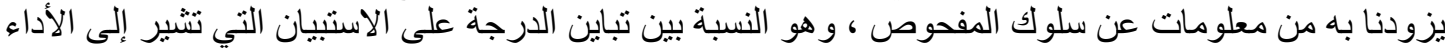

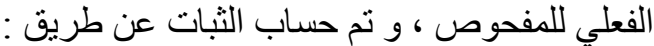

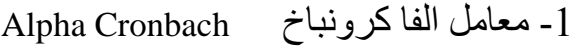

جدول (5) قيم معامل الثبات لمحاور الاستبيان

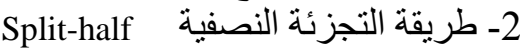

\begin{tabular}{|c|c|c|}
\hline التجزئة النصفية & معامل الفا & المحاور \\
\hline $0.839-0.777$ & 0.802 & المحور الأول : الانتماء الوطني \\
\hline $0.944-0.886$ & 0.911 & الدحور الثاني : الاطلاع على وثثيقة جودة الَّحياة 2020م \\
\hline $0.872-0.810$ & 0.846 & جودة الحياة الثالث : الدور في تعزيز الانتماء الفعلي البرطنامج \\
\hline $0.825-0.764$ & 0.793 & ثبات الاستبيان ككل \\
\hline
\end{tabular}

يتضح من الجدول السابق أن جميع قيم معاملات الثبات : معامل الفا ، التجزئة النصفية ، دالة عند مستوى 0.01

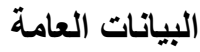

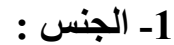

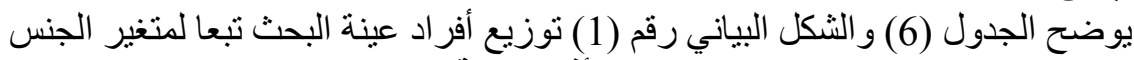

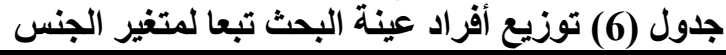

\begin{tabular}{|c|c|c|}
\hline النسبة\%\% & العدد & الجنس \\
\hline$\% 38.7$ & 116 & ذكور \\
\hline$\% 61.3$ & 184 & إناث \\
\hline$\% 100$ & 300 & المجموع \\
\hline
\end{tabular}


المجلة الحولية اللعلور الأسانية والإمتماعية International Journal of Humanities and Social Sciences website:www.ijohss.com Email:editor@ijohss.com ISSN: $2415-4822$

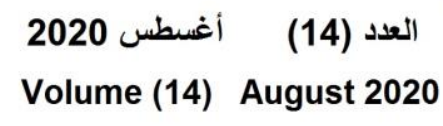
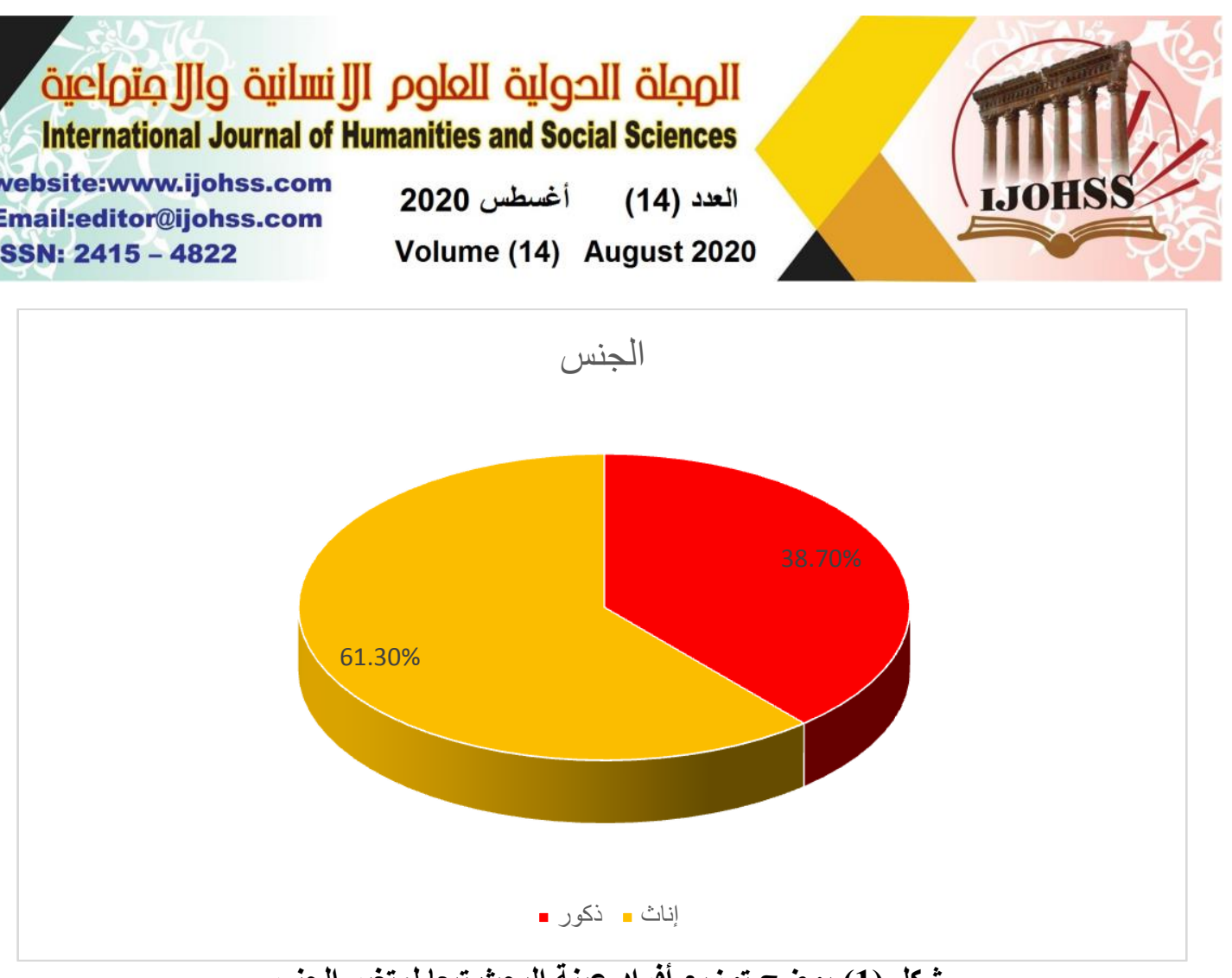

شكل (1) يوضح توزيع أفراد عينة البحث تبعا لمتغير الجنس

يتضح من جدول (6) وشكل (1) أن 184 من أفر اد عينة البحث إناث بنسبة 61.3\% ، بينما 116 من أفراد

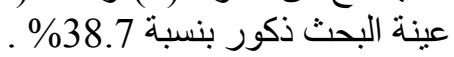

$$
\begin{aligned}
& \text { يوضح الجدول (7) و الثكل البياني رقم (2) توزيع أفر اد عينة البحث تبعا لمتغير الكلية } \\
& \text { جدول (7) توزيع أفراد عينة البحث تبعا لمتغير الكلية }
\end{aligned}
$$

\begin{tabular}{|c|c|c|}
\hline النسبة\%\% & العدد & الكلية \\
\hline$\% 65.7$ & 197 & كليات نظرية \\
\hline$\% 34.3$ & 103 & كليات عملية \\
\hline$\% 100$ & 300 & المجموع \\
\hline
\end{tabular}


المجلة الحولية اللعلور الأسانية والإمتماعية International Journal of Humanities and Social Sciences website:www.ijohss.com Email:editor@ijohss.com ISSN: $2415-4822$

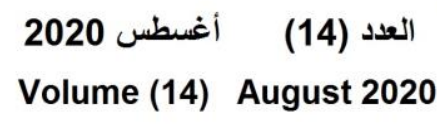
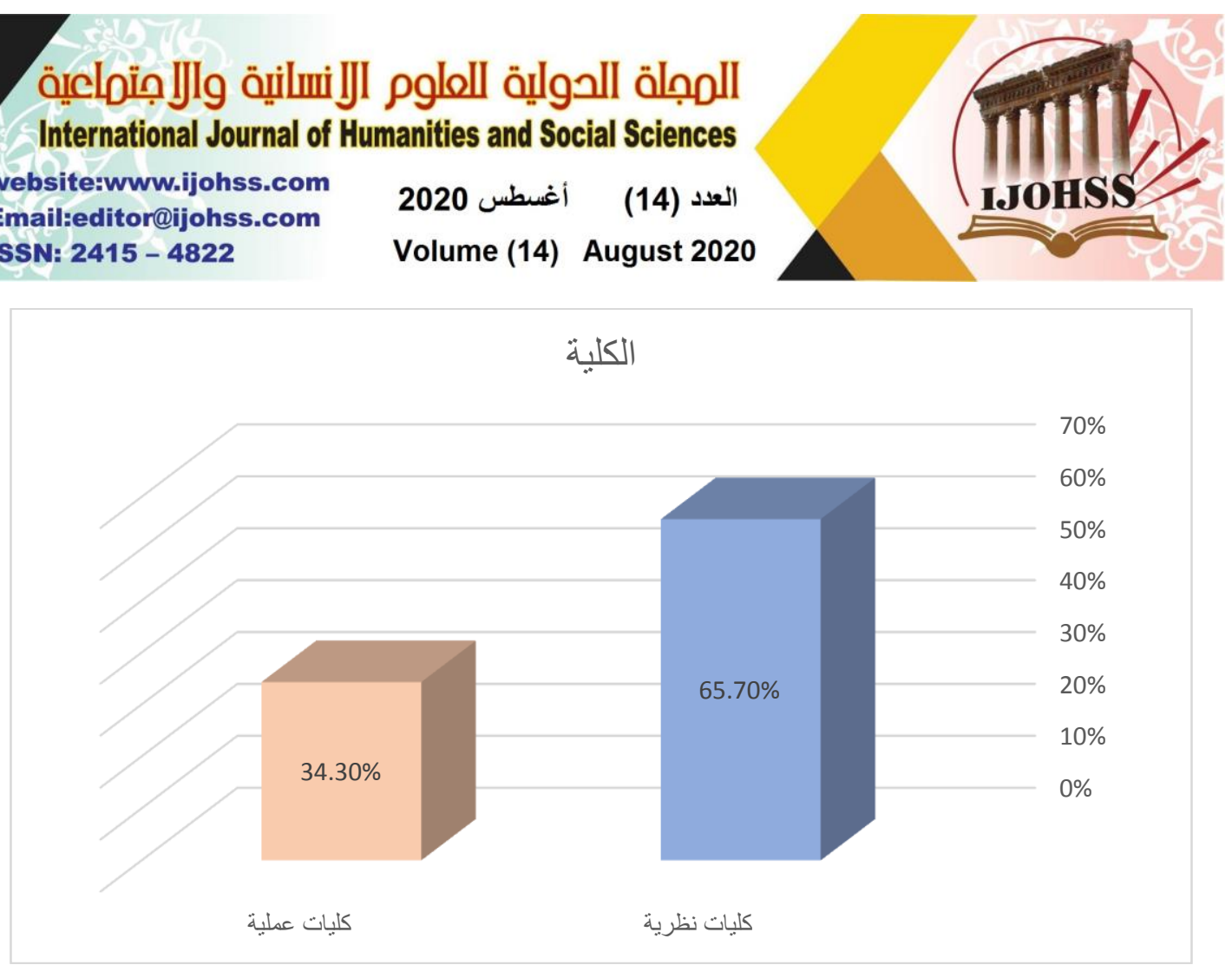

شكل (2) يوضح توزيع أفراد عينة البحث تبعا لمتغير الكلية

يتضح من جدول (7) وشكل (2) أن 197 من أفراد عينة البحث بكليات نظرية بنسبة 65.7\% ، بينما 103

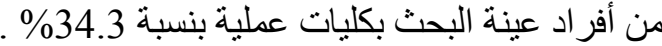

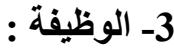

يوضح الجدول (8) والثكل البياني رقم (3) توزيع أفر اد عينة البحث تبعا لمتغير الوظيفة البوزية جدول (8) توزيع أفراد عينة البحث تبعا لمتغير الوظيفة

\begin{tabular}{|c|c|c|}
\hline النسبة\%\% & العدد & الوظيفة \\
\hline$\%$ \%44.3 & 133 & موظفين و إداريين \\
\hline$\% 55.7$ & 167 & أعضـاء هيئة التدريس \\
\hline$\% 100$ & 300 & المجموع \\
\hline
\end{tabular}

\section{الوظيفة}

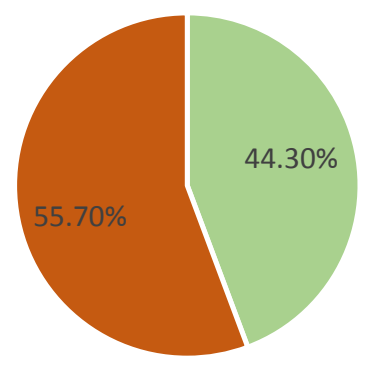

|- أعضاء هيئة التنريس | موظفين و إداريين

شكل (3) يوضح توزيع أفراد عينة البحث تبعا لمتغير الوظيفة 
المجلة الحولية اللعلوم الآنسانية والإمتماعية International Journal of Humanities and Social Sciences website:www.ijohss.com

Email:editor@ijohss.com العدد (14) أغطس 2020 ISSN: $\mathbf{2 4 1 5 - 4 8 2 2}$

Volume (14) August 2020

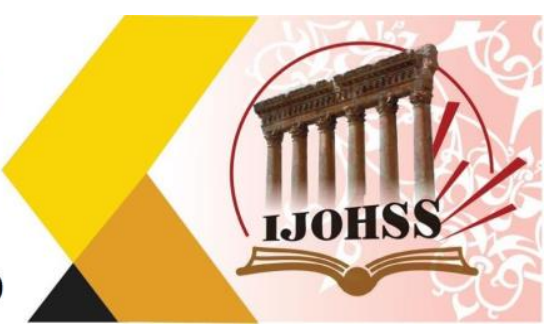

يتضح من جدول (8) وشكل (3) أن 167 من أفر اد عينة البحث أعضاء هيئة التدريس بنسبة 55.7\% ، بـاء بينما

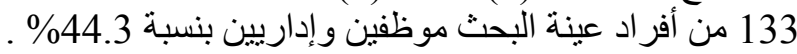

$$
\text { نتائج البحث : الفرض : }
$$

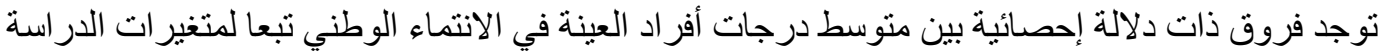

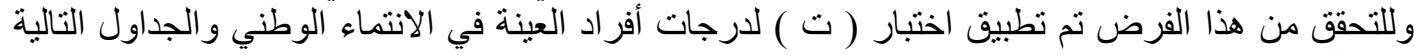

$$
\text { نوضح ذللك : }
$$

\begin{tabular}{|c|c|c|c|c|c|c|}
\hline الدلالة الد & 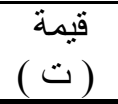 & الحرية & العينة & الانحريافي & الحسابي & الجنس \\
\hline \multirow{2}{*}{0.443 غير دال } & \multirow{2}{*}{0.938} & \multirow{2}{*}{298} & 116 & 2.410 & 26.251 & ذكور \\
\hline & & & 184 & 2.883 & 25.993 & إناث \\
\hline
\end{tabular}

جدول (9) الفروق في متوسط درجات أفراد العينة في الاتتماء الوطني تبعا لمتغير الجنس

$$
\text { الجنس }
$$

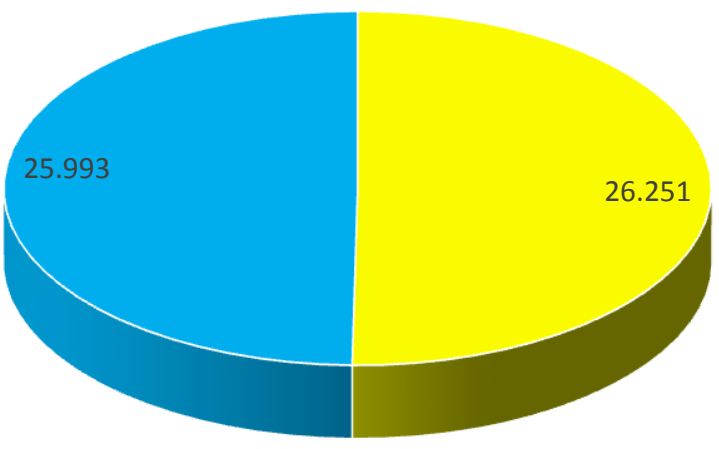

$$
\text { شكل (4) الفروق في متوسط درجات أفراد العينة في الانتماء الوطني تبعا لمتفير الجنس }
$$

\begin{tabular}{|c|c|c|c|c|c|c|}
\hline الدلالة & 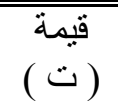 & الحرية & العينة & الالحعياري & الحسابي & الكلية \\
\hline \multirow{2}{*}{ دال عند الكليات العملية 0.05 لصالح } & \multirow{2}{*}{2.035} & \multirow{2}{*}{298} & 197 & 2.214 & 21.009 & كليات نظرية \\
\hline & & & 103 & 2.666 & 23.627 & كليات عملية \\
\hline
\end{tabular}

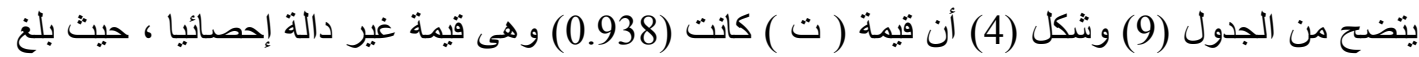
متوسط درجة الذكور (26.251) ، بينما بلغ منوسط درجة الإنة (9. الذكور و الإناث في الانتماء الوطني .

جدول (10) الفروق في متوسط درجات أفراد العينة في الانتماء الوطني تبعا لمتغير الكلية 
المجلة الحولية اللعلور الأسانية والإمتماعية International Journal of Humanities and Social Sciences website:www.ijohss.com Email:editor@ijohss.com العدد (14) أغطس 2020 ISSN: $2415-4822$ Volume (14) August 2020
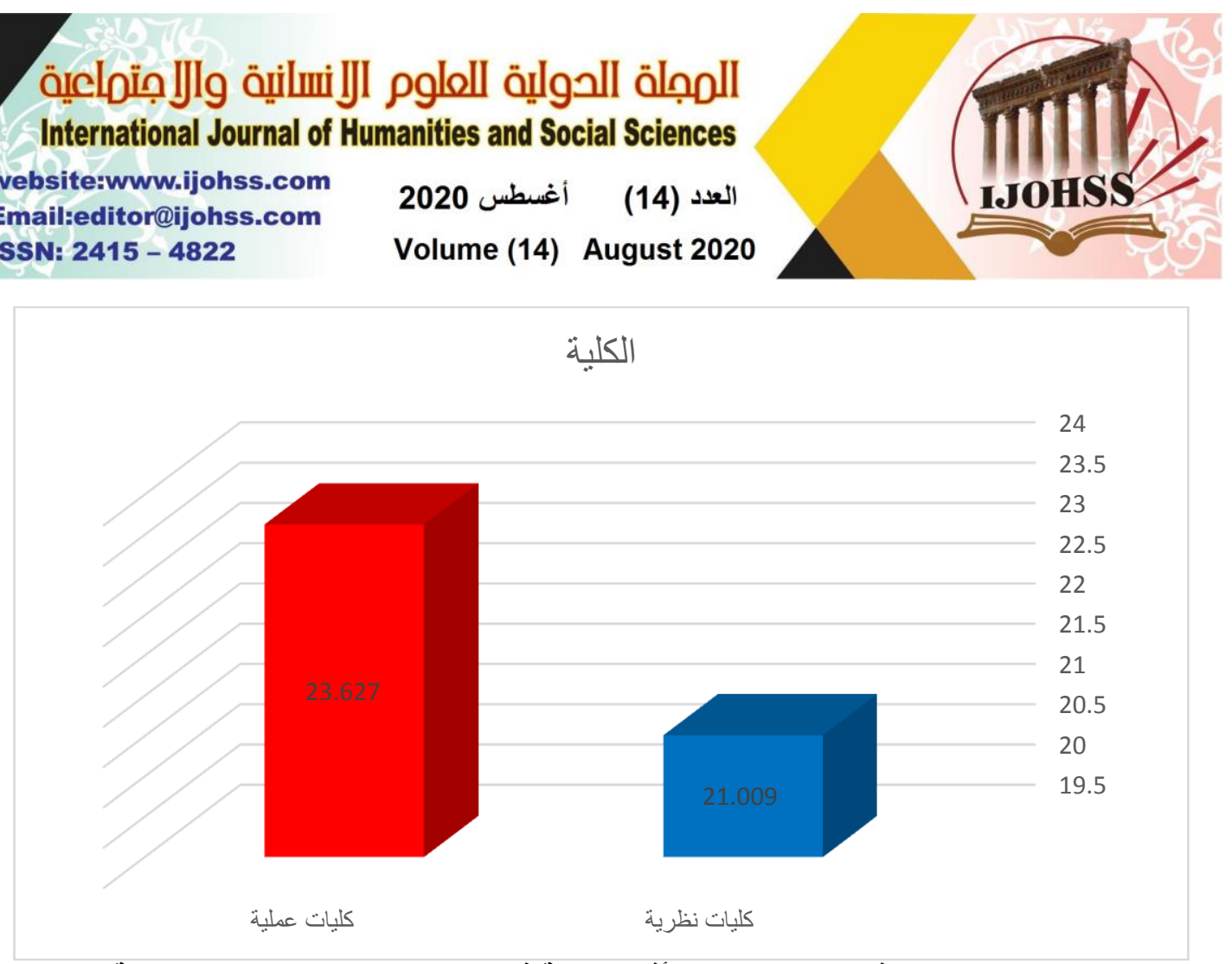

شكل (5) الفروق في متوسط درجات أفراد العينة في الانتماء الوطني تبعا لمتغير الكلية

يتضح من الجدول (10) وشكل (5) أن قيمة ( ت ) كانت (2.035) و هى قيمة دالة إحصائيا عند مستوى دلالة

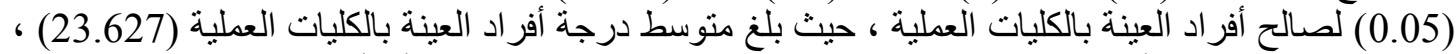

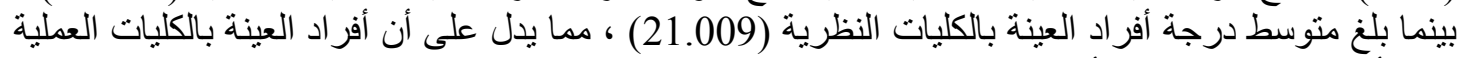
كانوا أكثر انتماء وطني من أفر اد العينة بالكليات النظرية النظية النظية

جدول (11) الفروق في متوسط درجات أفراد العينة في الانتماء الوطني تبعا لمتغير الوظيفة

\begin{tabular}{|c|c|c|c|c|c|c|}
\hline الدلالة & قاتمة & الدرجية & العينة & الالانحيرافي & الحتوسبي & الوظيفة \\
\hline \multirow{2}{*}{ لصالح أعضاء هيئة 0.01 لصندة } & \multirow[b]{2}{*}{7.113} & \multirow[b]{2}{*}{298} & 133 & 91.853 & 19.553 & موظفين وإداريين \\
\hline & & & 167 & 2.413 & 27.610 & هيئة التدريس \\
\hline
\end{tabular}




\section{الوظبفة}

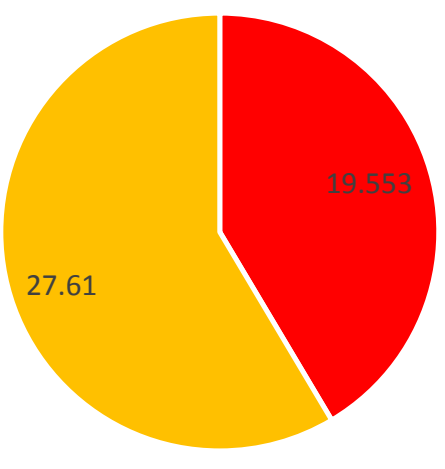

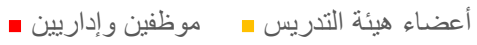

\section{شكل (6) الفروق في متوسط درجات أفراد العينة في الاتتماء الوطني تبعا لمتغير الوظيفة}

يتضح من الجدول (11) وشكل (6) أن قيمة ( ت ) كانت (7.113) و هى قيمة دالة إحصائيا عند مستوى دلالة

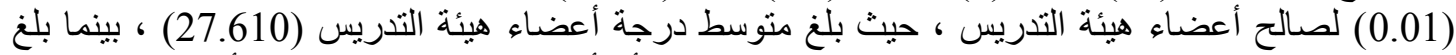
منوسط درجة الموظفين و الإداريين (19.553) ، مما يدل على أن أن أعضاء هيئة التدريس كانوا أكثر انتماء وطني

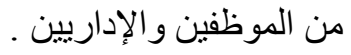

توجد فروق ذات دلالة إحصائية بين منوسط درجات أفراد العينة في الاطلاع على وثيقة جودة الحياة

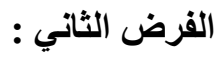

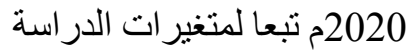

وللتحقق من هذا الفرض تم تطنيقات النيق اختبار ( ت ) لدرجات أفراد العينة في الاطلاع على وثيقة جودة الحياة

$$
\text { جلول (12) الفروق في متوسط درجات أفراد العينة في }
$$

\begin{tabular}{|c|c|c|c|c|c|c|}
\hline الدلالة & $\begin{array}{l}\text { قيمة } \\
(ت) \\
(ت)\end{array}$ & دالحرية & العينة & الانحر افياري & الحتوسطي & الجنس \\
\hline \multirow{2}{*}{ لصالح عند الذكور } & \multirow{2}{*}{13.625} & \multirow{2}{*}{298} & 116 & 2.221 & 29.021 & ذكور \\
\hline & & & 184 & 1.789 & 17.443 & إناث \\
\hline
\end{tabular}

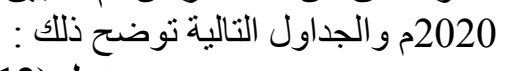

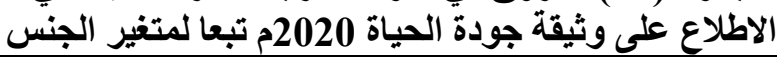


المجلة الحولية اللعلور الأسانية والإمتماعية International Journal of Humanities and Social Sciences website:www.ijohss.com Email:editor@ijohss.com ISSN: $2415-4822$ العدد (14) أغطط 2020 Volume (14) August 2020
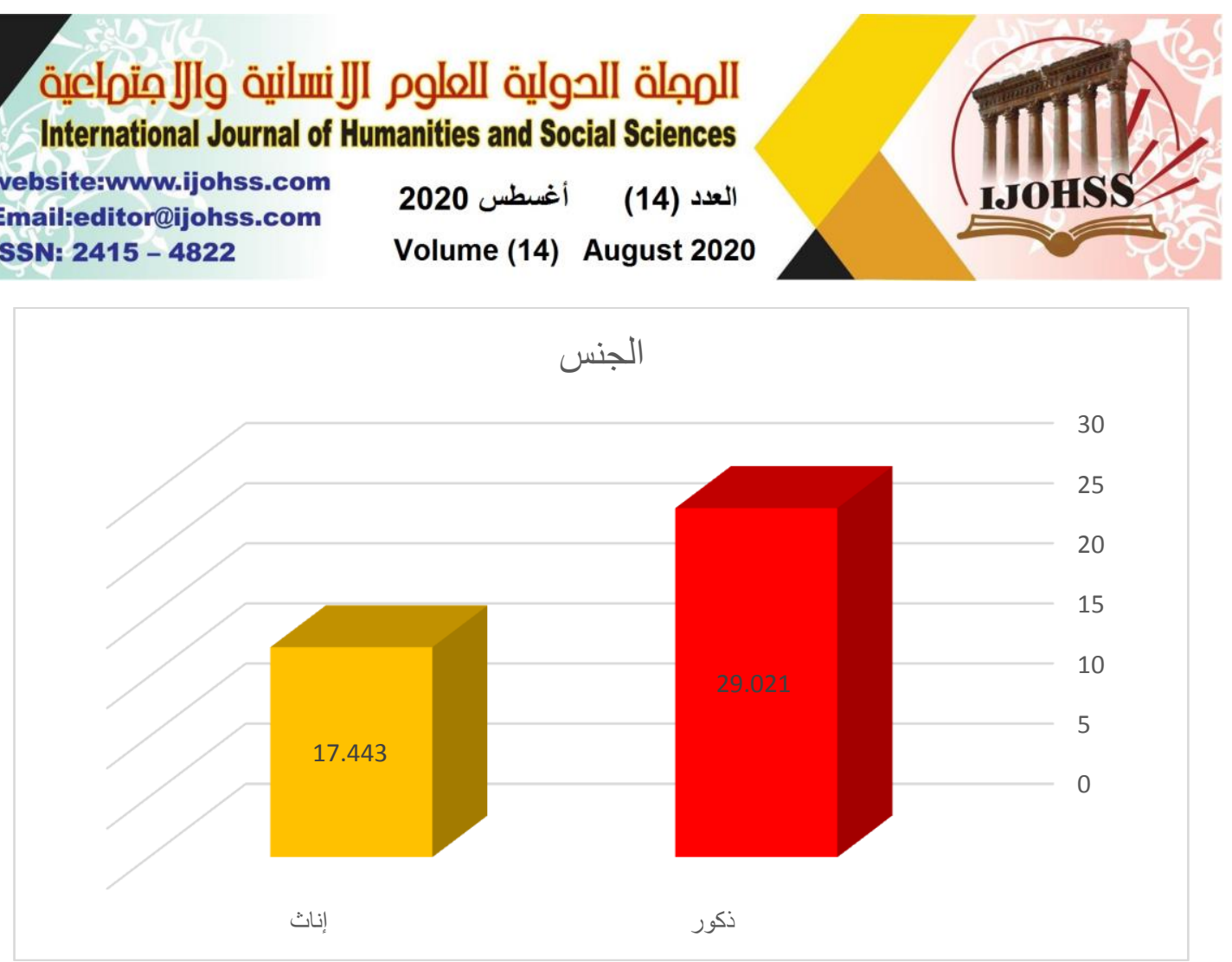

شكل (7) الفروق في متوسط درجات أفراد العينة في الاطلاع على وثيقة جودة الحياة 2020م تبعا لمتنير الجنس الجس

يتضح من الجدول (12) وشكل (7) أن قيمة ( ت ) كانت (13.625) وهى قيمة دالة إحصائيا عند مستوى

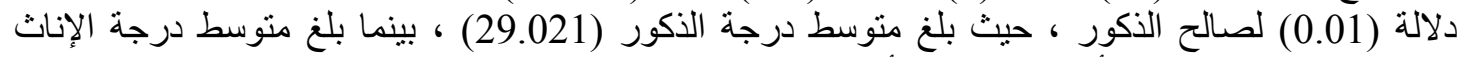
(17.443) ، مما يدل على أن الذكور كانوا أكثر اطلاع على وثيقة جودة الحياة 2020م من الإناث .

جدول (13) الفروق في متوسط درجات أفراد العينة في الاطلاع على وثيقة جودةً الحياة 2020م تبعا لمتغير الكلية

\begin{tabular}{|c|c|c|c|c|c|c|}
\hline الدلالة & قاتمة & الحرية & العينة & الانحراف & الحسابي & الكلية \\
\hline \multirow{2}{*}{ دال عند 0.01 لصالح العلية } & \multirow{2}{*}{11.113} & \multirow{2}{*}{298} & 197 & 1.329 & 15.539 & كليات نظرية \\
\hline & & & 103 & 2.008 & 24.142 & كليات عملية \\
\hline
\end{tabular}


المجلة الحولية للملوم الآنسانية والإمتماعية International Journal of Humanities and Social Sciences website:www.ijohss.com Email:editor@ijohss.com ISSN: $2415-4822$

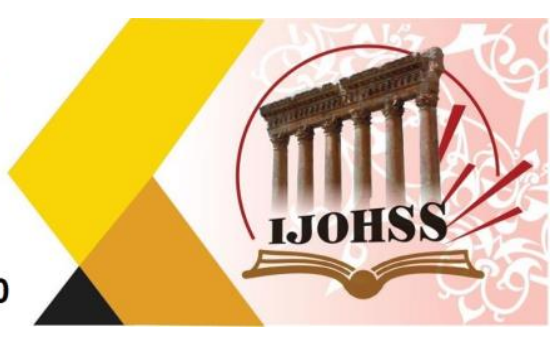

\section{الكلبة}

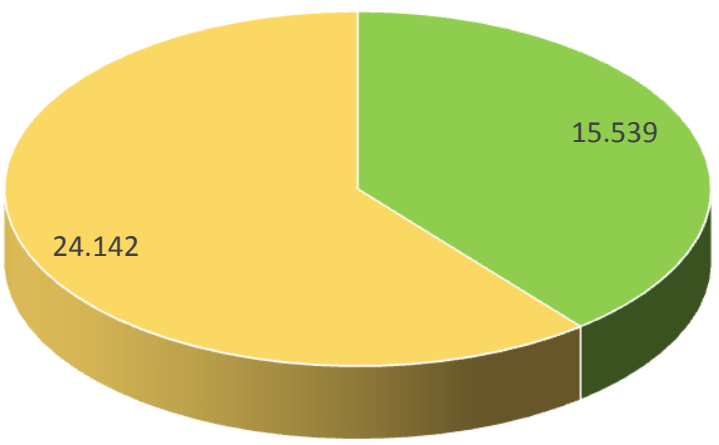

كلبات عملية - كلبات نظرية - -

شكل (8) الفروق في متوسط درجات أفراد العينة في

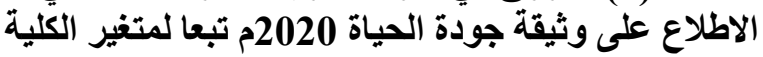

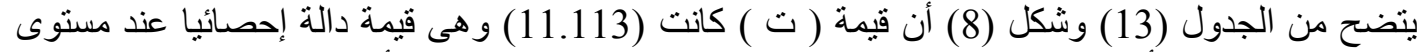

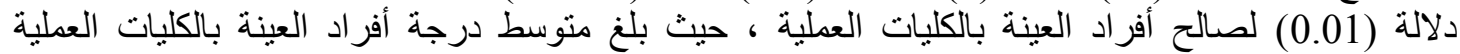

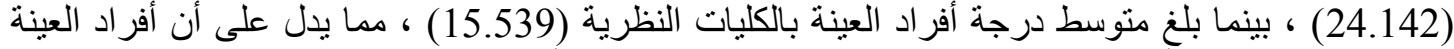

بالكليات العملية كانو أكثر اطلاع على وثيقة جودة الحياة 2020م من أفر اد العينة بالكليات النظرية .

جدول (14) الفروق في متوسط درجات أفراد العينة في

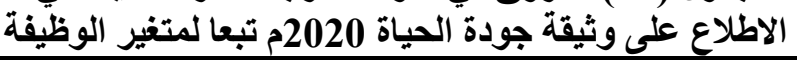

\begin{tabular}{|c|c|c|c|c|c|c|}
\hline الدلالة & قيمة (ت) & الحربة & العينة & الانحيراف & الحسابي & الوظيفة \\
\hline \multirow[b]{2}{*}{ أعضاء هيئة التدريس 0.01 لصالح } & \multirow[b]{2}{*}{10.152} & \multirow[b]{2}{*}{298} & 133 & 1.115 & 14.426 & موظفين و إداريين \\
\hline & & & 167 & 2.328 & 22.951 & أعضاء هيئة \\
\hline
\end{tabular}




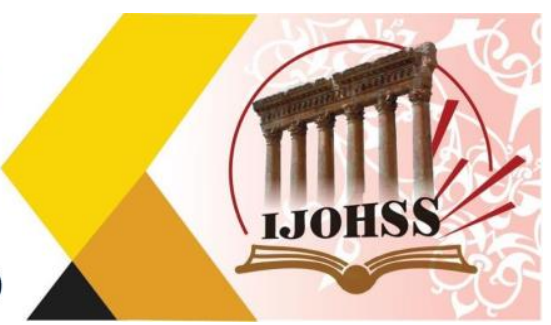

\section{الوظيفة}

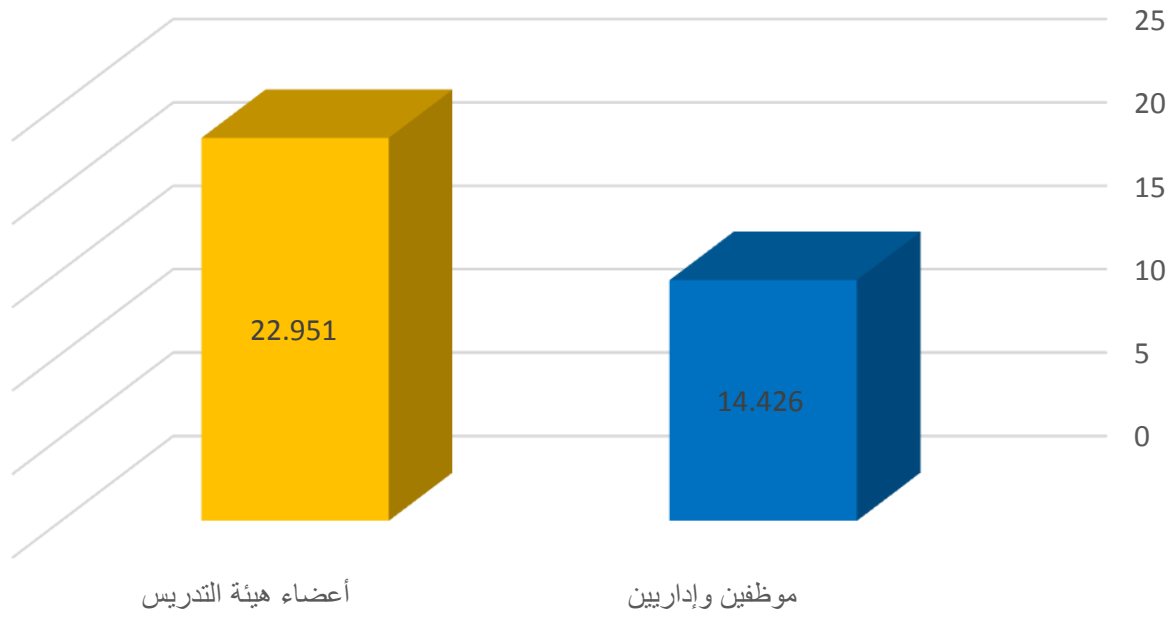

شكل (9) الفروق في متوسط درجات أفراد العينة في الاطلاع

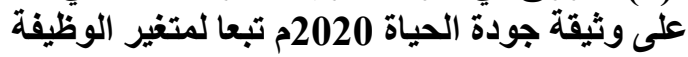

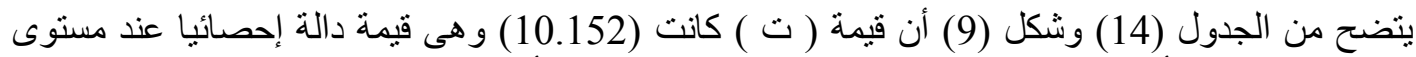

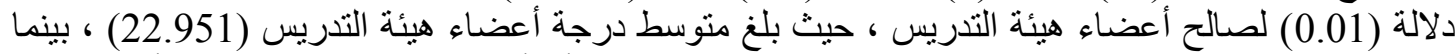

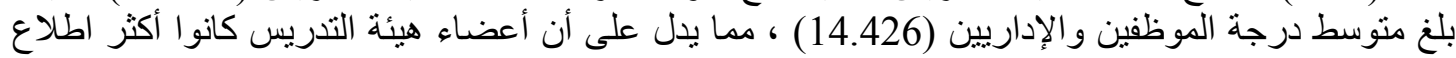

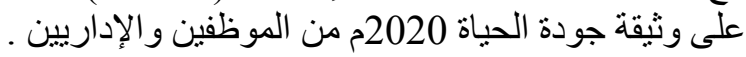

توجد فروق ذات دلالة إحصائية بين منوسط درجات أفر اد العينة في الدور الو اقعي و الفعلي لبرنامج جودة

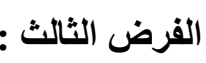

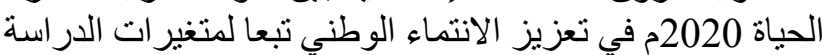

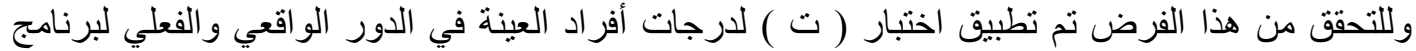
جودة الحياة 2020م في تعزيز الانتماء الوطني و الجداول التالية توضح ذلتك التران جدول (15) الفروق في متوسط درجات أفراد العينة في الدور الواقعي والفعلي الفي الفئي

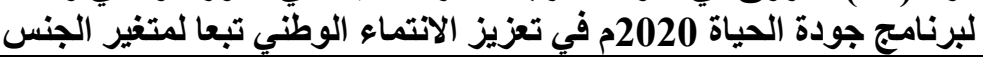

\begin{tabular}{|c|c|c|c|c|c|c|}
\hline الدلالة & $\begin{array}{l}\text { قيمة } \\
\text { (ت) }\end{array}$ & الحرجية & العينة & الالحياري & الحستبي & الجنس \\
\hline \multirow{2}{*}{ دال عند الإناث 0.01} & \multirow{2}{*}{5.205} & \multirow{2}{*}{298} & 116 & 3.002 & 34.175 & ذكور \\
\hline & & & 184 & 3.917 & 39.934 & إناث \\
\hline
\end{tabular}


المجلة الحولية اللعلور الأسانية والإمتماعية International Journal of Humanities and Social Sciences website:www.ijohss.com Email:editor@ijohss.com ISSN: $2415-4822$ العدد (14) أغطط 2020 Volume (14) August 2020
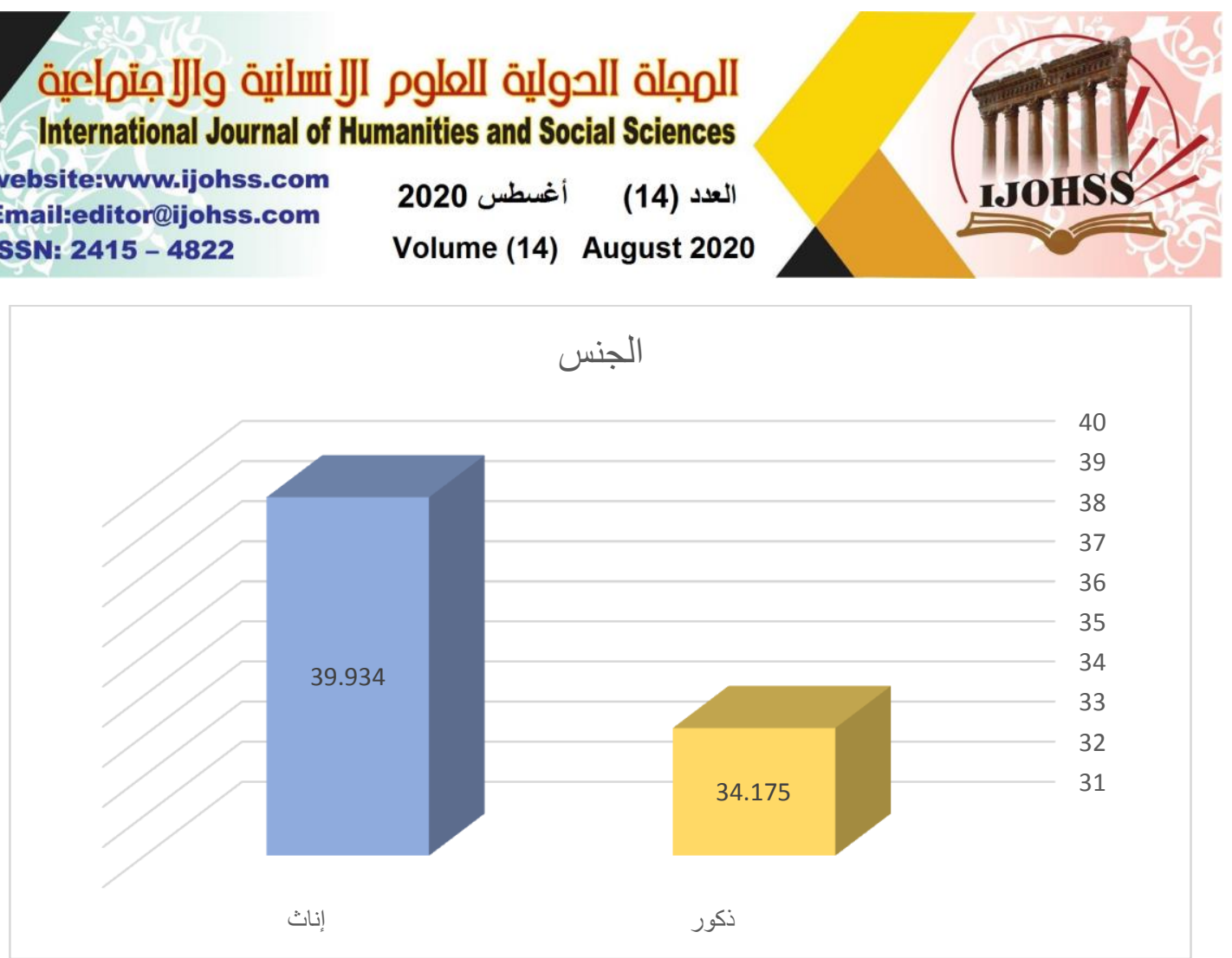

شكل (10) الفروق في متوسط درجات أفراد العينة في الدور الواقعي والفعلي التئي لبرنامج جودة الحياة 2020م في تعزيز الانتماء الوطني تبعا لمتغير الجنس

يتضح من الجدول (15) وشكل (10) أن قيمة ( ت ) ) كانت (5.205) وهى قيمة دالة إحصائيا عند مستوى الإنى

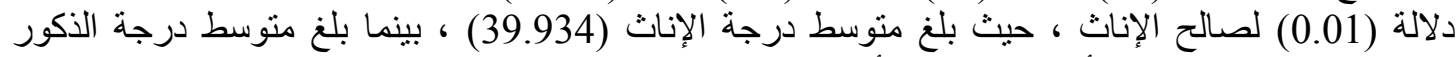

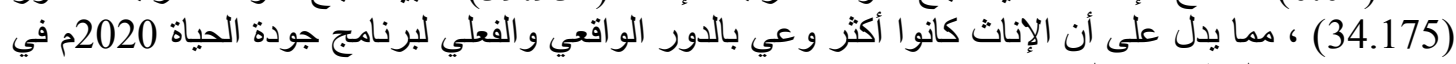
تعزيز الانتماء الوطني من الذكور ـ الأنات

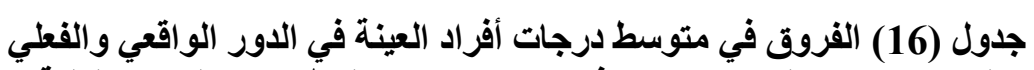
لبرنامج جودة الحياة 2020م في تعزيز الانتماء الوطني تبعا لمتغير الكلية الوفية

\begin{tabular}{|c|c|c|c|c|c|c|}
\hline الدلالة & قاتمة & دالحرية & العينة & المعياري & الحسابي & الكلية \\
\hline \multirow{2}{*}{ دال عند 0.01 لصلية الحملح } & \multirow{2}{*}{15.559} & \multirow{2}{*}{298} & 197 & 3.274 & 30.111 & كليات نظرية \\
\hline & & & 103 & 4.632 & 42.256 & كليات عملية \\
\hline
\end{tabular}


المجلة الحولية اللعلور الأسانية والإمتماعية International Journal of Humanities and Social Sciences website:www.ijohss.com Email:editor@ijohss.com ISSN: $2415-4822$

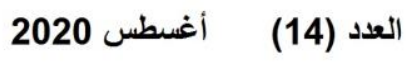

Volume (14) August 2020
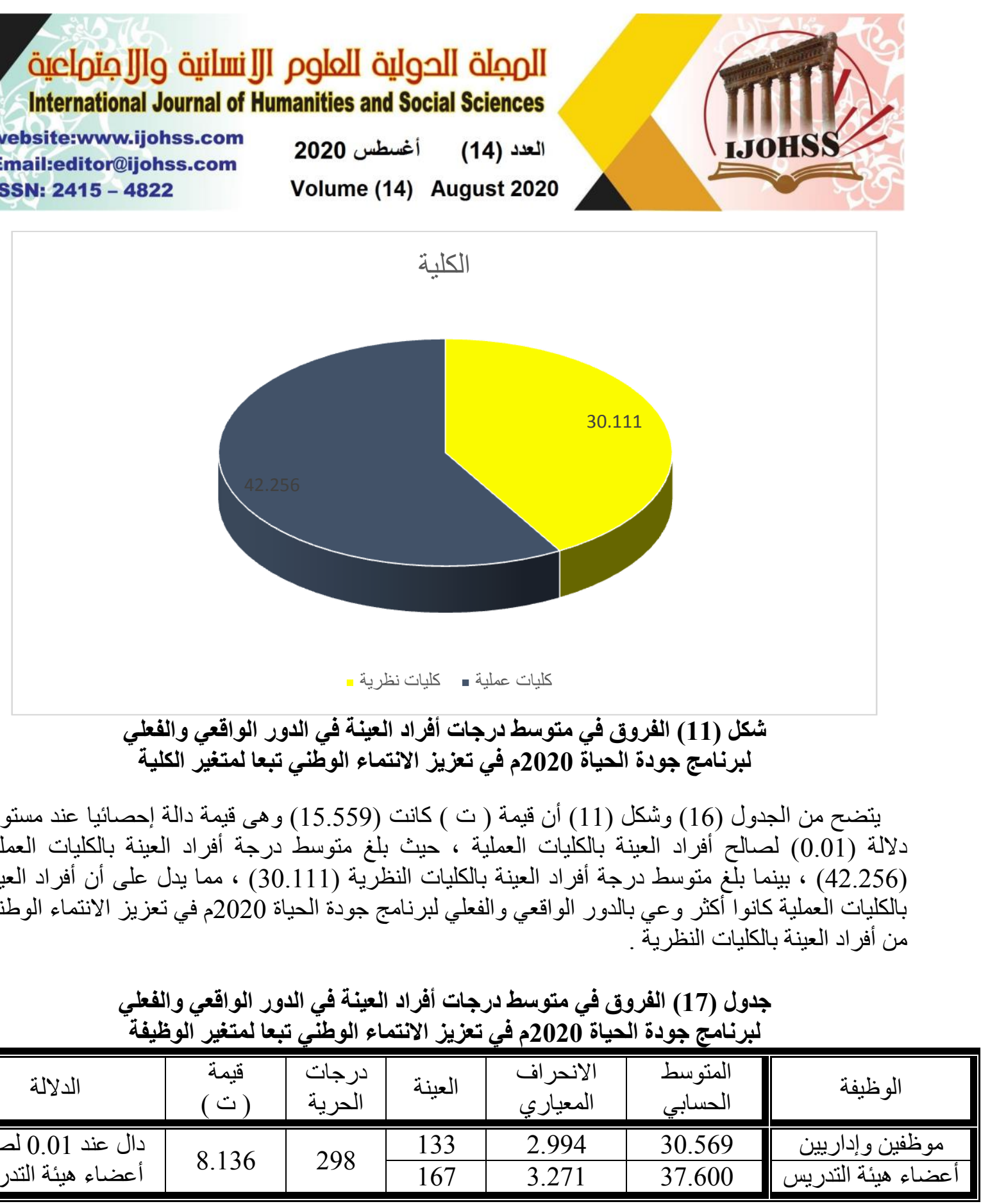
المجلة الدولية اللعلوم الآنسانية والإمتماعية International Journal of Humanities and Social Sciences website:www.ijohss.com Email:editor@ijohss.com ISSN: $2415-4822$

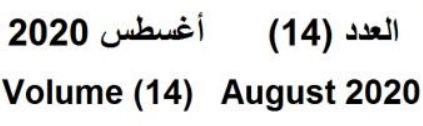

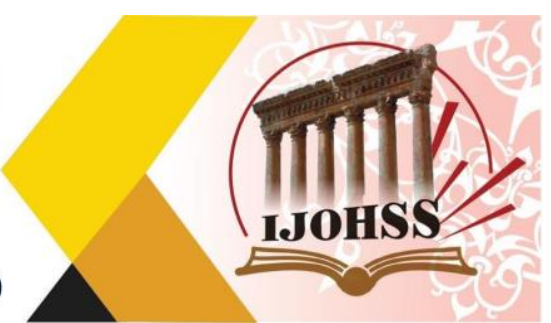

\section{الوظيفة}

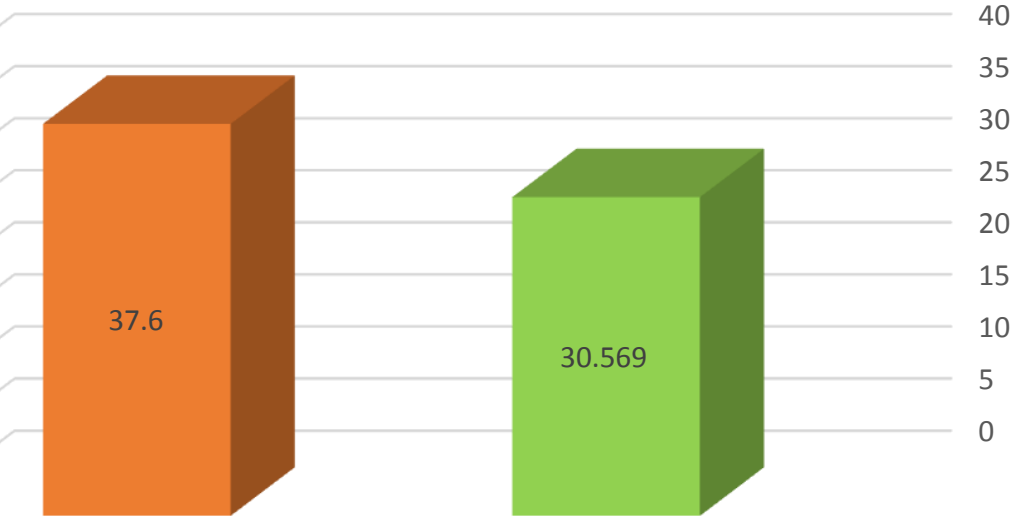

شكل (12) الفروق في متوسط درجات أفراد العينة في الدور الواقعي والفعلي لبرنامج جودة الحياة 2020م في تعزيز الانتماء الوطني تبعا لمتغير الوظيفة

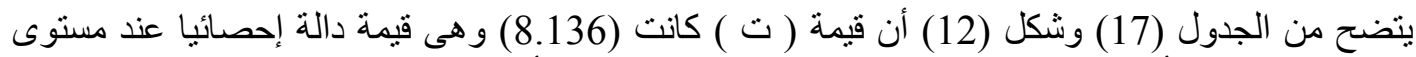

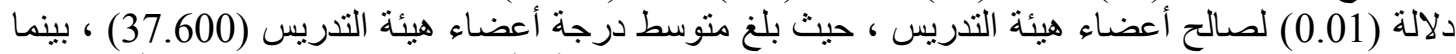

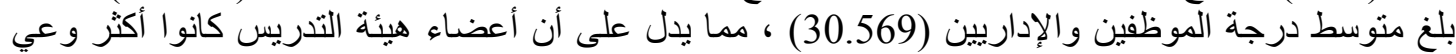

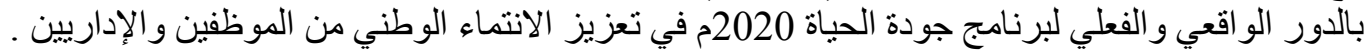

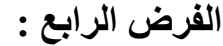
توجد علاقة ارتباطية بين محاور استبيان وثيقة برنامج جودة الحياة 2020م و أثر ها على الانتماء الوطني

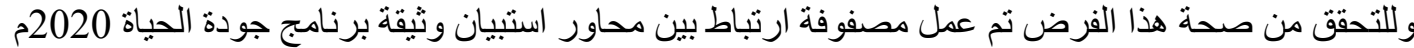
وأثر ها على الانتماء الوطني و الجدول التالي يوضح قيم معاملات الارتباط :

جدول (18) مصفوفة الارتباط بين محاور استبيان وثثيقة

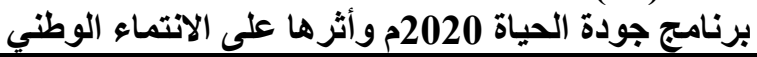

\begin{tabular}{|c|c|c|c|}
\hline لالدرنامج جودة الو اقعي والفعلية & الاطلاع على وثيقة جودة & الانتماء الوطني & \\
\hline & & - & الانتماء الوطني \\
\hline & - & *0.617 & الاطلاع على وثيقة جودة الحياة \\
\hline - & $* * 0.742$ & $* * 0.928$ & جودة الحياة الأحي و الفعلي لبرناءمج الوطني \\
\hline
\end{tabular}




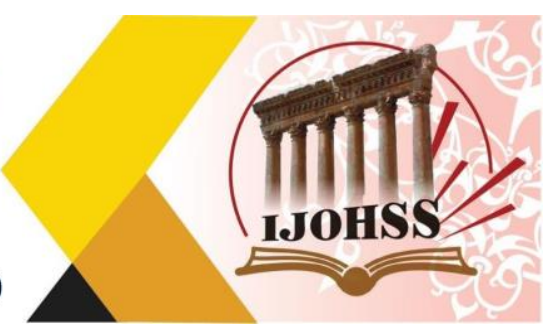

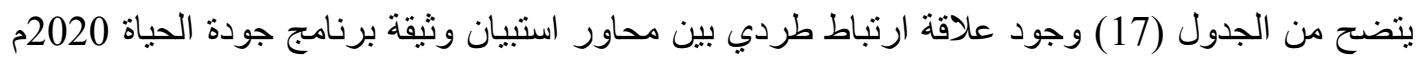

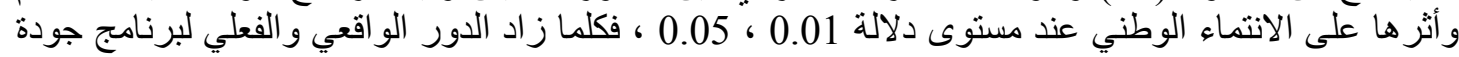

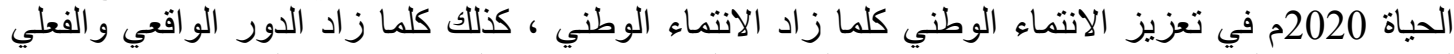
لبرنامج جودة الحياة 2020م في تعزيز الانتماء الوطني كلما زاد الاطلاع على وثيقة جودة الانياء الحياة 2020م .

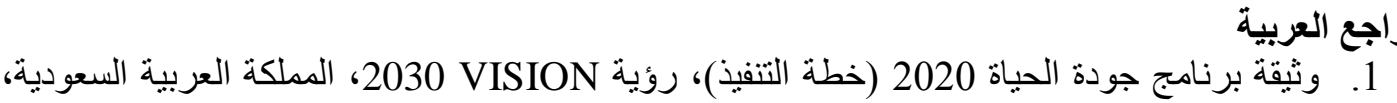

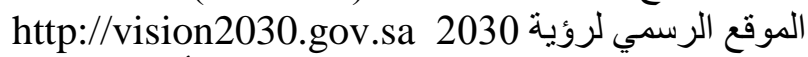

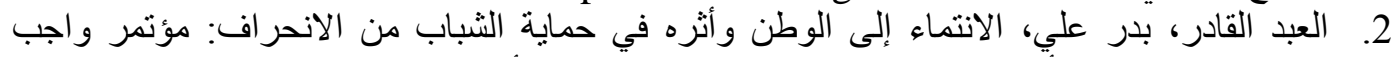

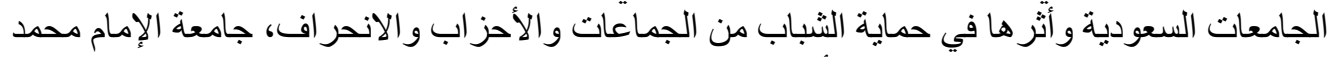

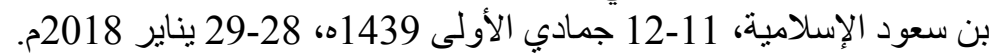

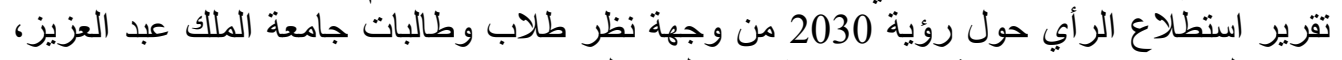

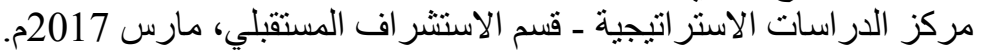

4. نتائج استطلاع ر أي إيجابية طلاب وطالبات جامعة الملك عبد العزيز، دركية مركز الدراسات الاستراتيجية ـ

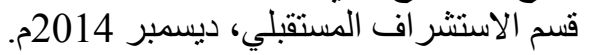
5. منصور ، حسن عبد الرزاق، الانتماء و الاغتر اب (در استة تحليلية)، سلسلة الفكر و الحضارة (1)، دار

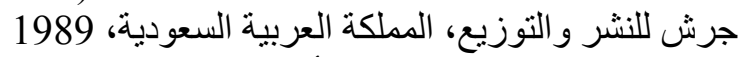

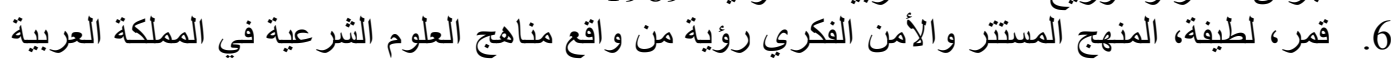

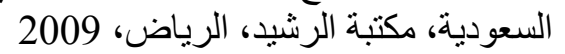
7. طه، أماني وعبد، الكريم، فاروق، الفية تربية المواطنة بين النظرية والتطبيق، مكتبة الأنجلو المصرية،

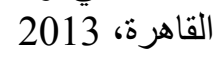

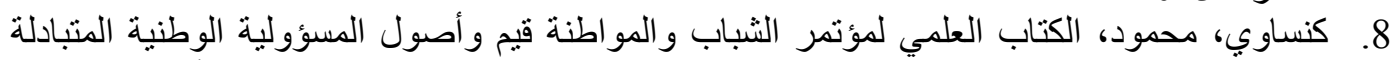

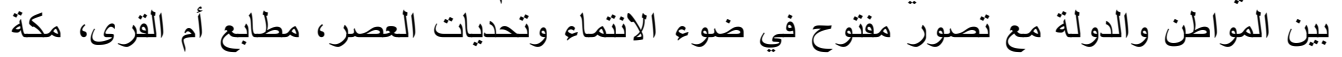

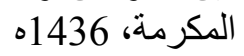

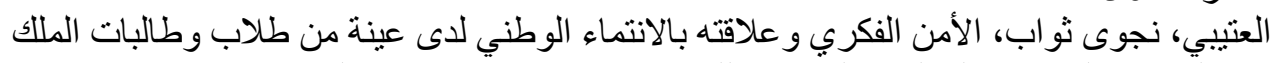

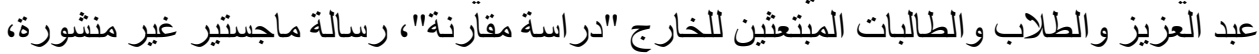

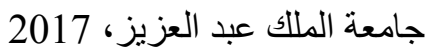

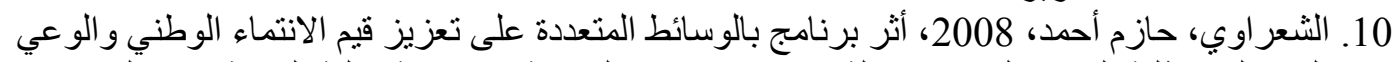

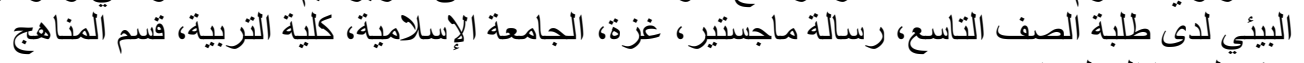
وتكنوليو لويا المعلومات.

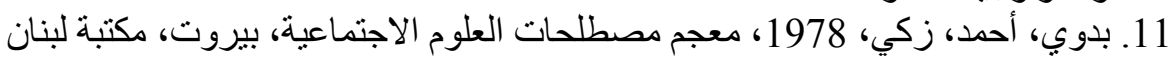

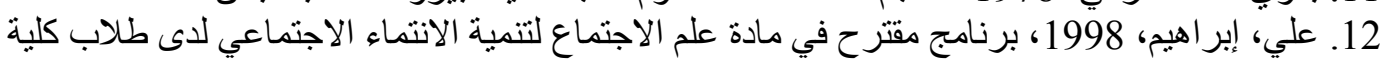

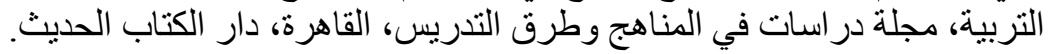

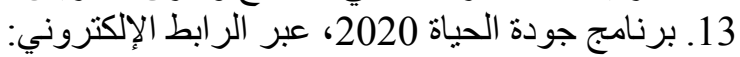
https://vision2030.gov.sa/sites/default/files/attachments/QoL\%20Arabic_0.pdf

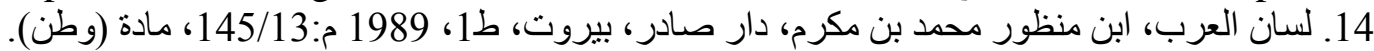
15. المورد الأكبر: قاموس إنجليزي- عربي حديث، رمزي منئ منير البعلبكي، دار العلم للملايين، بيروت، مادو ط . 2005 ، (1) 


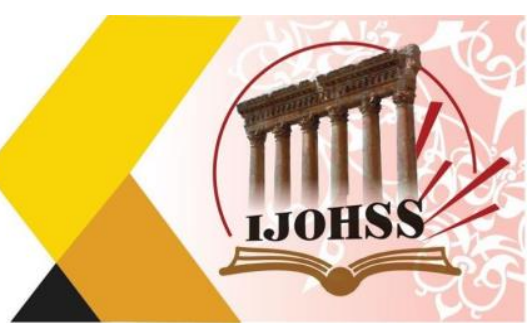

\section{References}

1. Quality of Life 2020 Program Document (Implementation Plan), VISION 2030 Vision, Kingdom of Saudi Arabia, 2030 Vision Official Website http://vision2030.gov.sa

2. Abdul-Qadir, Badr Ali, Belonging to the homeland and its effect on protecting young people from delinquency: the conference of Saudi universities' duty and its impact on protecting young people from groups, parties and deviation, Imam Muhammad bin Saud Islamic University, 11-12 Jumada I 1439 AH, 28-29 January 2018 CE.

3. The opinion report on the 2030 vision from the viewpoint of male and female students of King Abdulaziz University, Center for Strategic Studies - Department of Future Foresight, March 2017.

4. Positive opinion poll results for male and female students of King Abdulaziz University, Center for Strategic Studies - Department of Future Outlook, December 2014.

5. Mansour, Hassan Abdel-Razzaq, Affiliation and Alienation (Analytical Study), Series of Thought and Civilization (1), Dar Jerash for Publishing and Distribution, Kingdom of Saudi Arabia, 1989

6. Qamar, Latifa, The Curriculum and Intellectual Security: A Vision from the Reality of Sharia Sciences Curricula in the Kingdom of Saudi Arabia, Al-Rashid Library, Riyadh, 2009

7. Taha, Amani and Abdel-Karim, Farouk, Citizenship Education between Theory and Practice, The Anglo Egyptian Library, Cairo, 2013

8. Kansawi, Mahmoud, The Scientific Book of the Youth and Citizenship Conference, Values and Origins of Mutual National Responsibility between Citizen and the State with an Open Perception in the Light of Affiliation and Challenges of the Times, Umm Al-Qura Press, Makkah Al-Mukarramah, 1436 AH

9. Al-Otaibi, Najwa Thawab, Intellectual Security and its Relationship with National Affiliation with a Sample of Male and Female Students of King Abdulaziz and Male and Female Students Scholarships Abroad "A Comparative Study", Unpublished Master Thesis, King Abdulaziz University, 2017

10. Al-Shaarawy, Hazem Ahmed, 2008, The Impact of a Multimedia Program on Promoting the Values of National Belonging and Environmental Awareness for Ninth Grade Students, Master Thesis, Gaza, Islamic University, College of Education, Department of Curricula and Information Technology.

11. Badawi, Ahmed, Zaki, 1978, Lexicon of Social Sciences, Beirut, Lebanon Library 12. Ali, Ibrahim, 1998, a proposed program in the subject of sociology to develop social affiliation among students of the Faculty of Education, Journal of Studies in Curricula and Teaching Methods, Cairo, Dar Al-Kitab Al-Hadith.

13. Quality of Life 2020 program, via email:

14. https://vision2030.gov.sa/sites/default/files/attachments/QoL\%20Arabic_0.pdf

15. Tongue of the Arabs, Ibn Manzoor Muhammad bin Makram, Dar Sader, Beirut, I 1, 1989 AD: 13/145, Article (Watan). 


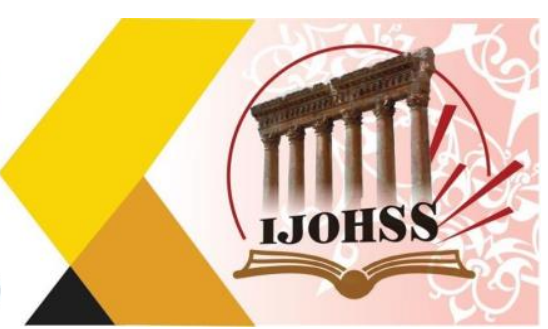

16. The Greatest Resource: Modern English-Arabic Dictionary, Ramzi Munir AlBaalbaki, Dar Al-Alam for Millions, Beirut, I (1), 2005.

17. Racial and Ethnic Differences in Advance Directive Possession: Role of Demographic Factors, Religious Affiliation, and Personal Health Values in a National Survey of Older Adults, (2016), Mary Ann Liebert, Inc., JOURNAL OF PALLIATIVE MEDICINE.19(2);149-156.

18. Political affiliation, collective self-esteem and perceived employability of immigrants: Inducing national identity polarizes host-nation employers, Todd Lucas, Evone Barkho, Monty Fakhouri, Lyke Tompson, International Journal of Intercultural Relations, Volume 39, March 2014, pages 136- 151.

19. Citizen preferences for possible energy policies at the national and state levels, David Feldman, Mark Peterson, Energy Policy, Volume 121, October 2018, pages 8091. 